\title{
MEASURING THE ECONOMIC IMPACT AND HEALTH RISKS OF PESTICIDE RESIDUES IN POTATOES AND GRAPES CROPS
}

\author{
KADAH, T. M. SAIED ${ }^{1}$ and A. M. ELMARSAFY ${ }^{2}$
}

1. Agricultural Economics Research Institute.

2. Central Laboratory of Residue analysis of Pesticides and Heavy Metals in Food, Agricultural Research Center.

(Manuscript received 24 April 2018)

\begin{abstract}
$\mathrm{T}$ he research aims to study pesticide residues on potatoes and grapes to improve and develop the management of integrated control programs, reduce economic losses and do not harm human health, To achieve this, the research relied on the results of the sample data collected from some local markets of some governorates of the Republic, Pesticide residues were evaluated and potential risks assessed for food containing pesticide residues exceeding the maximum allowable limit for each crop.

The most important results of the study:

The results of the analysis of the sample of the study, which included 79 samples, potato yield 44 samples, grapes 35 samples, showed that the number of samples free of pesticide residues 31 samples represent $39.24 \%$ of the total samples, The number of samples contaminated with pesticide residues was 48 samples representing $60.76 \%$ of the total samples. The number of samples exceeding the maximum allowable residues (MRLs) of 16 pesticides represented $33.3 \%$ of the total samples contaminated with
\end{abstract} pesticide residues.

- $\quad$ The study also showed the emergence of some organic chlorine pesticides banned since 1972 in some potato crop samples in Assiut governorate.

- $\quad$ The results of the study show the presence of some pesticides that exceeded the limit allowed daily intake (EDI), according to what the Food and Agriculture Organization (FAO), and the World Health Organization (WHO): Carbofuran with a risk index of about $1128 \%$, or more than the daily intake of about $1028 \%$, followed by the pesticide dezynone with a risk index of about $168 \%$ more than the daily intake of $68 \%$.

\section{Recommendations:}

1- $\quad$ To tighten control on pesticides that are not allowed to be used and to track smuggled pesticides to prevent their circulation in local markets.

2- Raising awareness and training for farmers in the Upper Egypt governorates to rationalize the use of pesticides and methods of applying them with optimum economic efficiency to reduce pollution and the absence of pesticide residues beyond the permissible limits.

3- Continued pesticide residue monitoring programs in all food products to provide and update a database through which future strategies for pest control and consumer protection can be implemented through random exposure to pesticides.

4- Directing the producers of the grapes to rationalize the use of pesticides because they use large amounts and different types of pesticides, which leads to pollution of the crop and thus causing significant economic losses. 


\title{
قياس الأثر الاقتصادي والمخاطر الصحية لمتبقيات المبيدات \\ في محصولي البطاطس و العنب
}

\section{طاهر محمد سعيد قدح و أشرف محمود المرصفي}

\author{
1 1

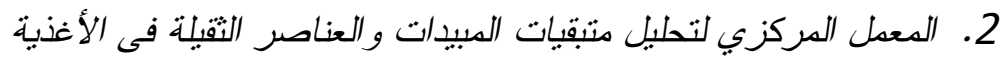

\section{مقدمة}

يعد إستخدام المبيدات أحد أهم المدخلات الزراعية التى لايمكن الإستغناء عنها سواء فى هله

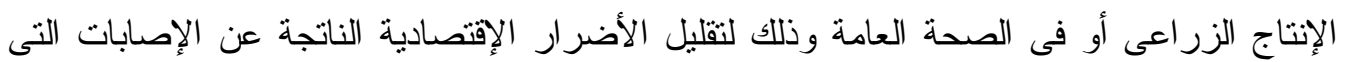
تسبيها الحشرات أوغير ها من الآفات التى تصيب المحاصيل الزر اعية، لذا فقد إرتفع معدل الإنتاج العالمى للمبيدات الكيميائية من حوالي 1.8 مليون طن عام 1975 إلى حوالي 5 مليون طن عام 2015، كما قدر الإستهلاك العالمي للمبيدات الكيميائية بحوالى 7560 مليون دولان عام 1978

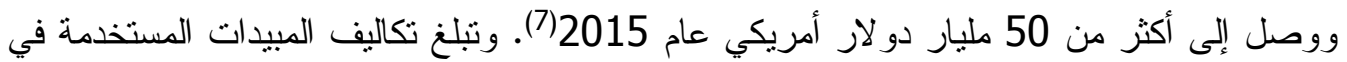
الإنتاج الزراعي في مصر حوالي 950 مليون جنيه، كما بلغ إجمالي المستهلك من المبيدات

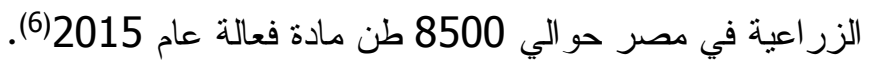
وقد نطورت عملية مكافحة الآفات إلى استخدام مجموعة من التقنيات الحديثة بتو افق دقيق دادي يعتمد على الإستفادة القصوى من الوسائل الطبيعية والحيوية من خلال منظور بيئى واقتصادى

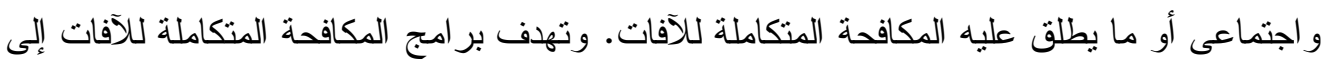
الحفاظ على نشاط الأعداء الحيوية وعدم الإضرار بصحة الإنسان وسلامة البيئة مع زيادة القدرة التنافسية لتصدير منتجات زر اعية خالية من متبقيات المبيدات. ويعتبر محصولي البطاطس و العنب من المحاصيل الهامة إقتصادياً حيث بلغ إنتاج كل منهما

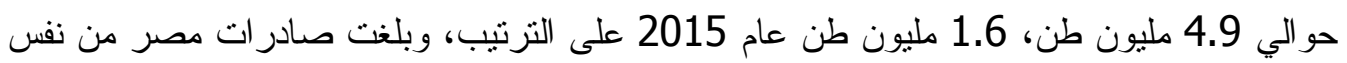
المحصولين 618 ألف طن، 124 ألف طن بقيم قدرت بحو الي 224 مليون دو لار ، 240.6 مليون دولار عام 2015(1).

\section{مشكلة البحث}

تتعرض المحاصيل الزر اعية لكثير من الآفات والأمر اض بسبب الظروف المُنَاخية، مما

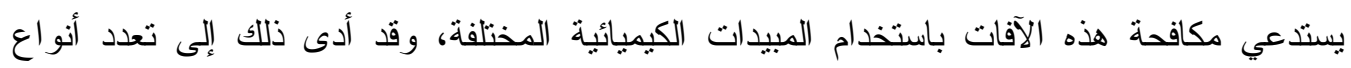

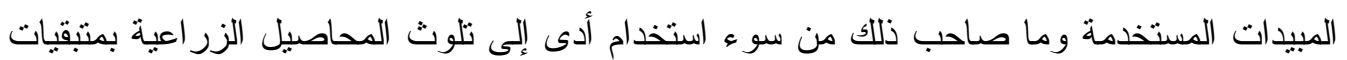
المبيدات بعد حصادها، مما أدى إلى رفض الكثير من الثحنات المصدرة وزيادة نسب التلوث بمتبقيات المبيدات بالمنتجات الزراعية بالأسو اق المحلية مما تسبب في حدوث خسائر اقتصادية كبيرة و الإضر ار بالمستهلكين المصريين. 


\section{أهداف البحث}

در اسة متبقيات المبيدات على محصولي البطاطس و العنب لتحسين وتطوير إدارة بر امج المكافحة المتكاملة وتقليل الخسائر الاقتصادية و عدم الإضر ار بصحة الإنسان من خلال:-

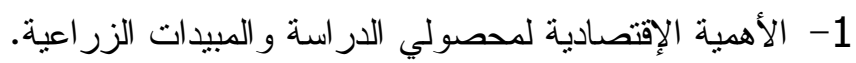

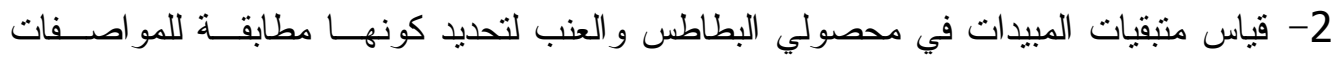

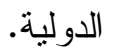

3- تحديد مستويات ومصادر التلوث بعينة الدراسة في الأسواق المحلية.

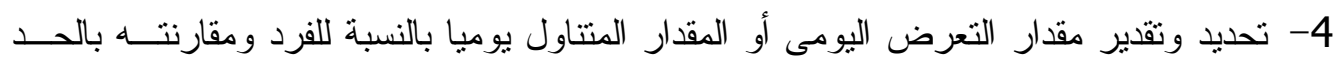
المقبول تتاوله بومياً (ADI) وبالتالى ثقييم الأخطار المتوقعة على لونى صحة الإنسان نتيجة ما يتتاوله من غذاء بمحصولي البطاطس و العنب. 5- قياس الأثز الإقتصادي لمتبقيات المبيدات في البطاطس ولمن والعنب. الأسلوب البحثي ومصادر البيانات

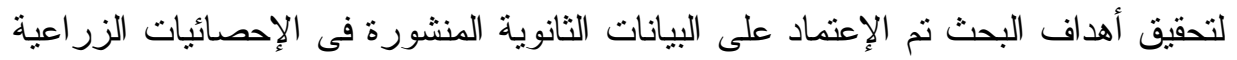

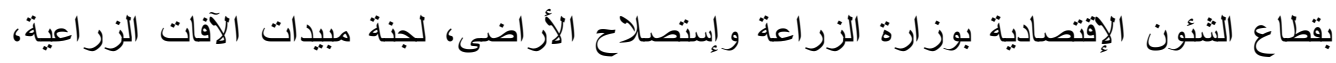

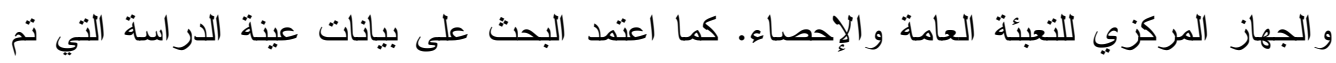
جمعها من بعض أسواق الجملة لبعض محافظات الجمهورية بواسطة المعمل المركزى لتحليل

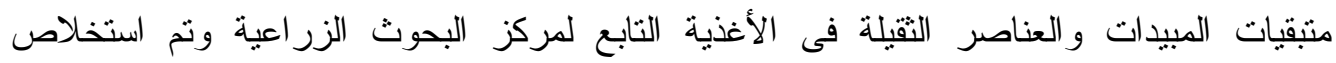
وتجهيز العينات للتحليل باستخدام طريقة Quick, Easy, Cheap, Effective, Rugged, QuEChERS (9) و التى تستخدم لاستخلاص مجمو عة كبيره من متبقيات المبيدات تصل إلى أكثر من (and Safe)

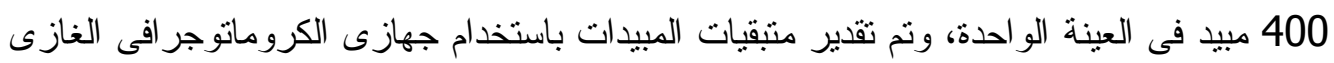

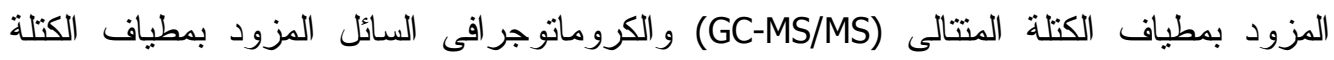

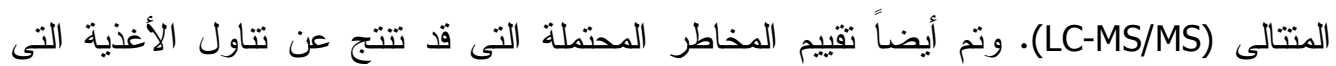
تحتوى على منبقيات مبيدات أكبر من الحد الأقصى المسموح به على كل محصول. كما استتد البحث إلى أساليب التحليل الإحصائي من الناحيتين الوصفية والتئية الكمية، كاستخدام

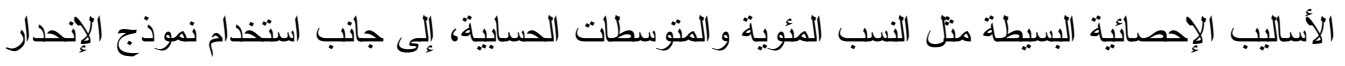

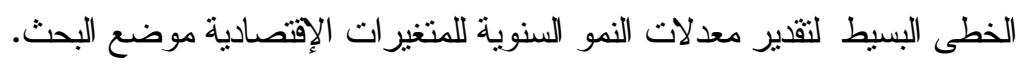
الإطار النظري والتحليلي للبحث:

$$
\text { - - أهم النتائج في ضوء الار اسات السابقة: }
$$

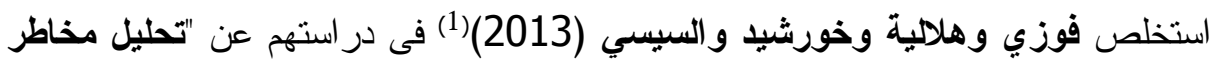

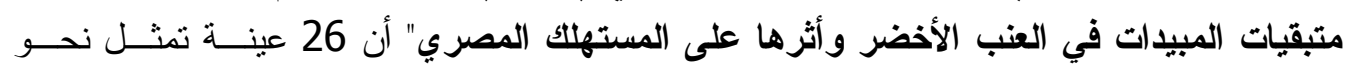

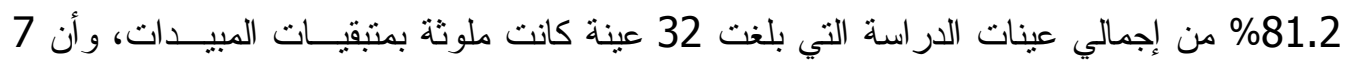

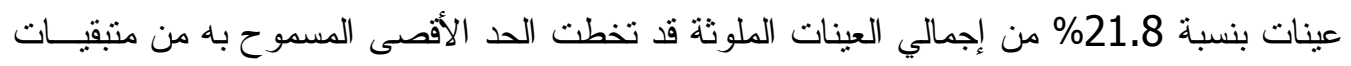

(1) F.I. Eissa1, A.A. Helalia, M.A. Khorshid, M.A. El-Sisi, Monitoring of multi-class pesticide residues in green grape and their potential risk for Egyptian consumers, Nature and Science 2013;11(11), www.sciencepub.net/nature/ns.. 


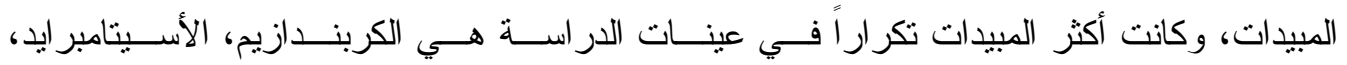
الثايهالورين، البروفينوفوس.

كما أثنارت سهرة ونور الدين (2016)(2 ) إلى أن تطبيق نظام المكافحة المتكاملة له آثـار

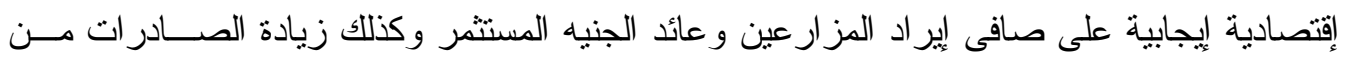

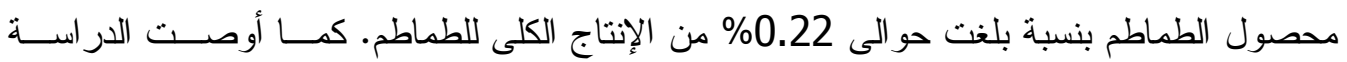
بتقعيل الدور الإرشادى لكى يقوم بتوعية وتدريب الزراع على إستخدام برنامج المكافحة المتكاملة.

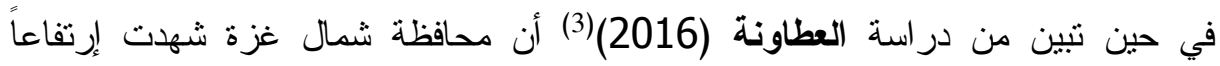

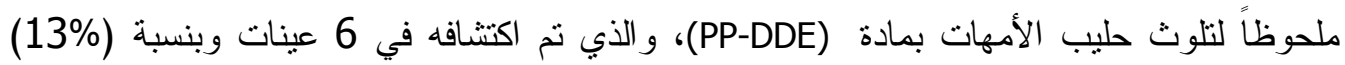
من نسبة محافظات غزة و البالغة (32.6\%) ولعل ذللك يرجع إلى الإفر اط في استخدام المبيدات في شمال غزة، وتلتها محافظة خان يونس وشكلت نسبة (10.8\%) ومن ثم محافظة رفح وشكلت نسبة (6.5\%) ثم محافظة غزة وشكلت نسبة (2.2\%)، أما محافظة الوسطى فلم بظهر بالعينات أي تلوث

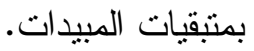

ويتبين مما سبق أهمية قياس مبتقيات المبيدات صحياً واقتصادياً في المحاصيل الزراعية والمنتجات الغذائية لتحديد نسب التلوث ومناطقه وأكثر المبيدات التي تسبب حدوث خسائر اقتصادية بالقطاع الزراعي.

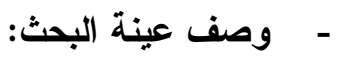

يقوم المعمل المركزي لتحليل متبقيات المبيدات والعناصر الثقيلة في الأغذية بقياس تلوث الأغذية بمتبقيات المبيدات وذلك من خلال برنامج تقصى متنقيات المبيدات فى عينات الخضر المبر و الفاكهة بالأسو اق المحلية بأكثر من 10 محافظات في مصر وقد تم اختيار 6 محافظات ضمت بنت أكثر عينات محصولي الدراسة (البطاطس و العنب) كما أن هذه المحافظات بها أهم الأسواق المركزية وذللك خلال موسمي 2015/2014 وكان إجمالي عدد عينات العينة لكلا المحصولين 79 عينة تم جمعها من أسو اق هذه المحافظات كما يلي: القاهرة 14 عينة، المنوفية 10 عينات، البحيرة 17 عينة

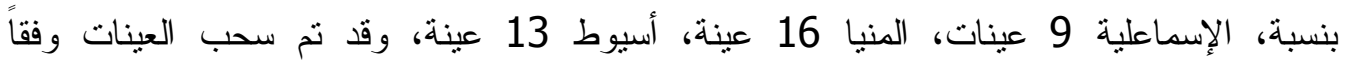
لمو اصفات هيئة الدسنور الغذائي (الكودكس) حيث يمر جمع العينات بعدة مر احل تبدأ بالعينات

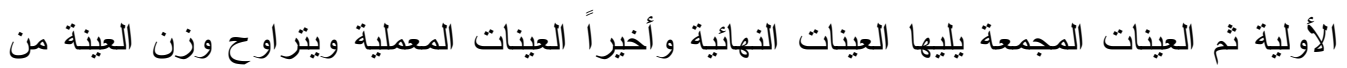
2- 5 كيلو جر ام تقريباً، كما أن تكلفة تحليل هذه العينات تكون مرتفعة للغاية حيث يصل تكلفة تحليل العينة الو احدة إلى أكثر من 1800 جنيه غير شاملة سحب العينة و النقل. بعض المصطلحات والتعريفات الهامة(17): تعريف مبيدات الآفات الزراعية:

أى مادة أوخليط من المو اد نستخدم فى منع، تدمير، إبادة، أو جذب أو طرد أو مكافحة آفة

(2) سهرة خليل عطا ، محمد محمود نور الدين (دكتور)، التقييم الاقتصادى للمكافحة المتكاملة، المجلة المصرية للأقتصاد

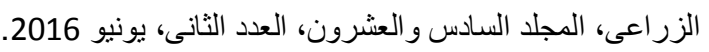

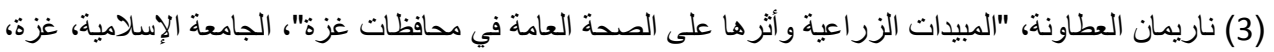


بما فيها الأنواع النباتية أو الحيو انية غير المرغوبة أثناء إنتاج أوتخزين أو نقل أو توزيع أو تصنيع

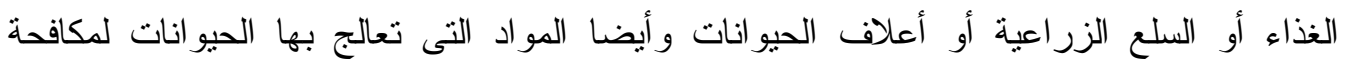
الطفيليات الخارجية ويشمل المصطلح المواد المجفة التى تستخدم كمنظمات نمو نباتية أو مسقطات أور اق و عادة فإن المصطلح يستثىى منه الأسمدة و المغذيات النباتية والحيو انبة ومو اد الإضافة للأغذية و الأدوية البيطرية.

Pesticide Residues : متبقيات المبيدات الادوبه

يقصد بها أى أثر لمادة معينة بالغذاء أو السلع الزراعية أو أعلاف الحيوانات ناتجة من

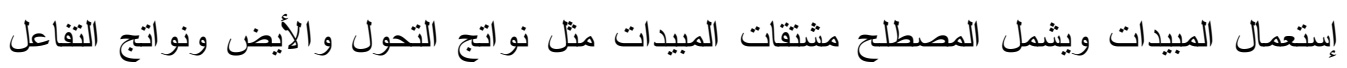
و الثوائب التى تعنبر ذات أهمية سمية وأيضا فإن المصطلح يشمل المتنقيات غير معلومة المصادر أو التى لا يمكن تجنبها.

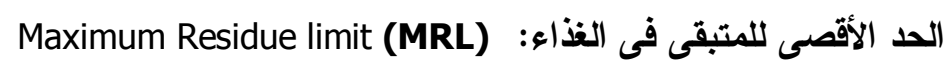
الحد الأفصى من تركيز متبقيات المبيدات المسموح بنو اجده فى الغذاء ويقاس بالملليجر ام/كجم.

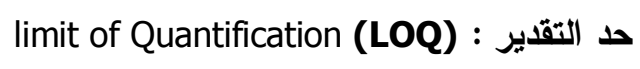
الحد الذى يبدأ عنده تقدير المتبقى من المبيد أو أقل أو أدنى تركيز من المتبقى الذى يمكن تعريفه أو

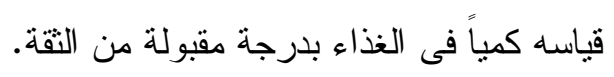

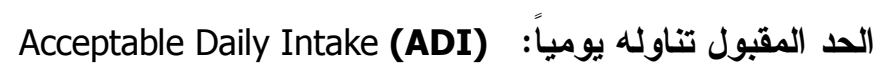
يقصد بها كمية متبقيات المبيدات التى يتتاولها الفرد يومياً من جر اء تتاوله لأغذية ملوثنة

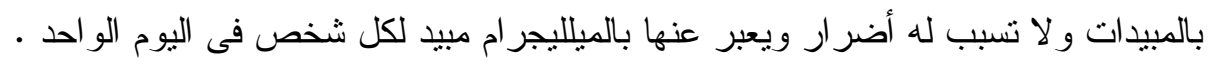

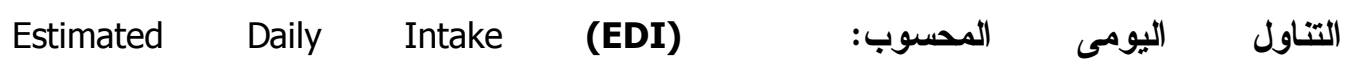
يقصد بها حساب كمية منتقيات المبيدات التى ينتاولها الفرد يومياً من جر اء تتاوله أغذية ملوثة

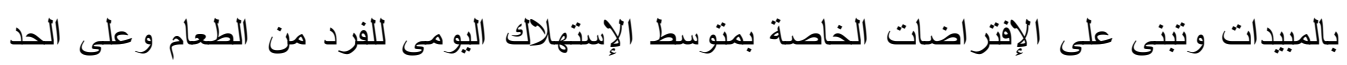

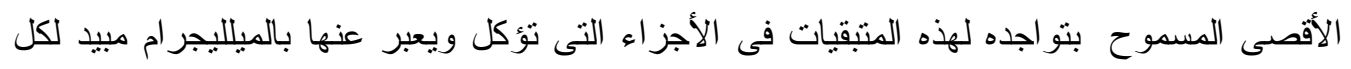
شخص فى اليوم الو احد. نتائج البحث

الأهمية الإثتصادية لمحصولى الاراسة :

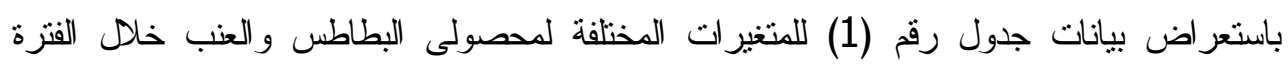
(2015-2005) نبين أن جميع المؤشرات اتجهت نحو الزيادة مع إختلاف معدلات النمو السنوي لها، وفيما يلى نتائج تقدير ات كل محصول على حده: أولاًا : محصول البطاطس:

تثتير بيانات الجدول إلى أن المساحة المزروعة بالبطاطس على مستوى الجمهورية خلال منوسط

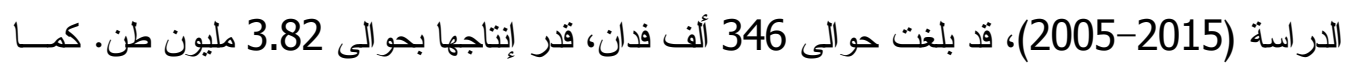
ينيين من نفس الجدول أن هنالك اتجاهاً نحو التوسع فى إنتاج البطاطس فى مصر، وقد اتجه هذا التوسع نحو 
زيادة إجمالى الرقعة المزروعة بها بدرجة ملحوظة ومن ثم زيادة كية الناتج، حيث بلغت المساحة حو الى

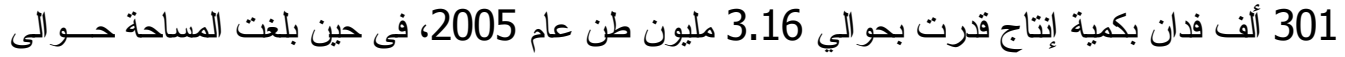
437 ألف فدان بكمية إنتاج قدرت بنحو 4.95 مليون طن عام 2015، بمعدل زيادة قدر بنحو 45.5\%،

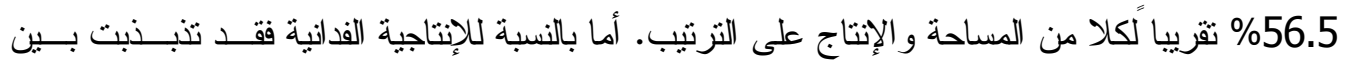

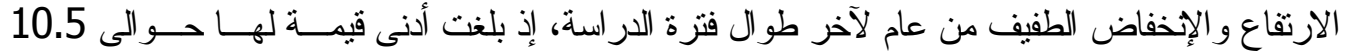
طن/فدان عام 2006، و أقصى قيمة لها حوالى 11.3 طن/فدان عــام 2015، وبمتوســط عــام للفتــرة

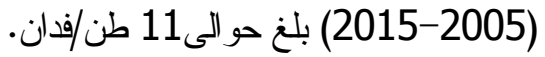

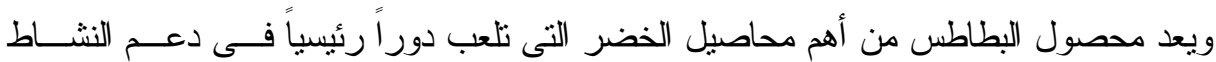
الإقتصادي للاولة، حيث أنه تتو افر لديه المقومات لزيادة صادر اته للأسو اق الخارجية، و أيضـا تتـــو افر

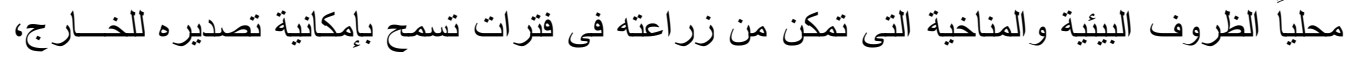

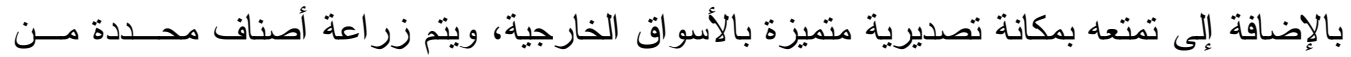
البطاطس لغرض التصدير وخاصة لدول الإتحاد الأوروبى و الذى ينطلب مو اصفات خاصة سو اء في

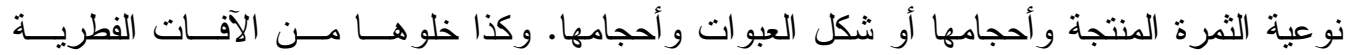
و الحشرية. وتثتير بيانات نفس الجدول أن كمية صادرات البطاطس المصرية خلال الفترة (2005-

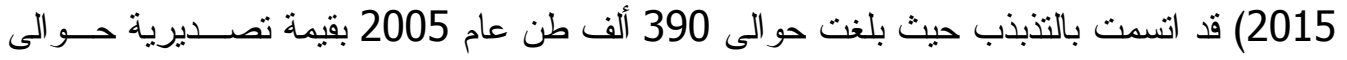
77 مليون دو لار و انخفضت لأدنى مستوى لها خلال فترة الدر اسة إلى 82 ألف طن بقيمة 55 مليون

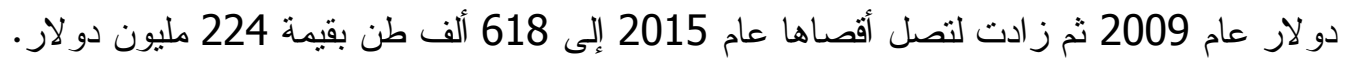

\section{جدول (1)}

تطور بعض المتغير ات الإتتاجية و الاقتصادية لمحصولى البطاطس والعنب

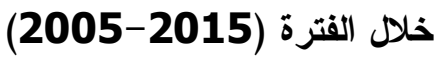

\begin{tabular}{|c|c|c|c|c|c|c|c|c|c|c|c|}
\hline \multicolumn{6}{|c|}{ العب } & \multicolumn{5}{|c|}{ البطاطس } & \multirow[b]{2}{*}{ السنوات } \\
\hline لدليمة & ألف طعية & (الإنتاج & 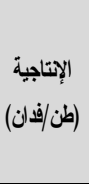 & الف الفمرة & الكلية (ألف & لصليد & ألف طيدة & (الفنتاج & (طان/فانل) & (ألف & \\
\hline 16.8 & 24.6 & 1392 & 9.6 & 145 & 160 & 77 & 390 & 3167 & 10.5 & 301 & 2005 \\
\hline 21.9 & 27.8 & 1432 & 9.7 & 147 & 166 & 65 & 366 & 2313 & 10.5 & 220 & 2006 \\
\hline 59.6 & 53.7 & 1485 & 9.9 & 149 & 171 & 106 & 382 & 2760 & 10.7 & 257 & 2007 \\
\hline 161.4 & 196.3 & 1531 & 10.0 & 154 & 167 & 39 & 86 & 3567 & 10.9 & 327 & 2008 \\
\hline 225.6 & 154.9 & 1370 & 9.0 & 152 & 167 & 55 & 82 & 3659 & 11.1 & 330 & 2009 \\
\hline 198.6 & 274.1 & 1360 & 8.9 & 152 & 164 & 118 & 272 & 3634 & 10.9 & 335 & 2010 \\
\hline 210.0 & 623.3 & 1321 & 8.6 & 154 & 172 & 117 & 357 & 4338 & 11.1 & 391 & 2011 \\
\hline 223.2 & 83.0 & 1379 & 8.7 & 158 & 189 & 115 & 271 & 4758 & 11.3 & 422 & 2012 \\
\hline 182.8 & 88.8 & 1435 & 8.7 & 164 & 193 & 168 & 352 & 4265 & 11.2 & 381 & 2013 \\
\hline 242.2 & 245.7 & 1596 & 9.3 & 172 & 193 & 266 & 557 & 4611 & 11.3 & 410 & 2014 \\
\hline 240.6 & 124.0 & 1687 & 9.5 & 178 & 197 & 224 & 618 & 4955 & 11.3 & 437 & 2015 \\
\hline 162.1 & 172.4 & 1453 & 9.3 & 157 & 176 & 123 & 339 & 3821 & 11.0 & 346 & المتوسط \\
\hline
\end{tabular}

المصدر: (1) وز ارة الزر اعة و استصلاح الأر اضي- قطاع الشئون الإقتصادية- الإدارة المركزية للإقتصاد الزر اعي و الإحصاء- نثرة الاقتصاد 
ثاتياً: : محصول العنب:

يشير الجدول (1) إلى أن المساحة الكلية المزروعة بمحصول العنب على مســتوى الجمهوريــة

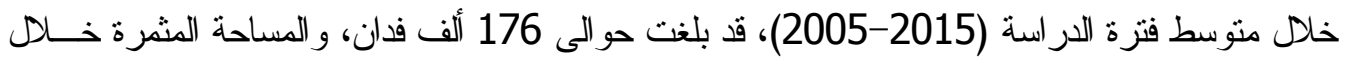
متوسط نفس الفترة حو الى 157 ألف فدان ، قدر إنتاجها بحوالى 1.453 مليون طن. كما يتنين أن هنــاك اتجاه نحو التوسع فى إنتاج العنب فى مصر ، وقد اتجه هذا التوسع نحو زيادة إجمالى الرقعة المزروعة بها بدرجة ملحوظة ومن ثم كمية الناتج، إذ بلغت حوالى 160 ألف فدان بإنتاج بلغ نحو 1.39 مليون طن عام 2005، فى حين بلغت المساحة حو الى 197 ألف فدان بإنتاج قدر بنحو 1.68 مليون طن عـام 2015،

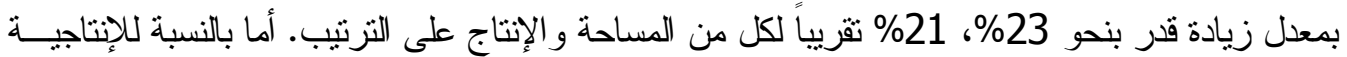
الفدانية فقد تذبذبت بين الإرتفاع و الإنخفاض الطفيف من عام لآخر طوال فترة الدراسة، إذ بلغت أدنى قيمة

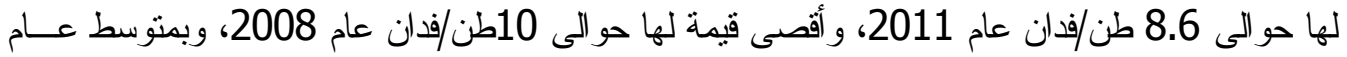
للفترة (2015-2005) بلغ حو الى 9.3 طن/فـدان.

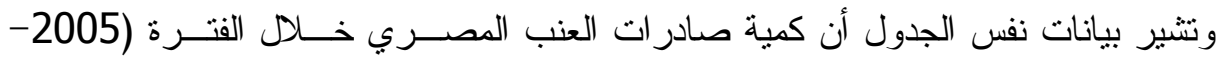

2015) قد اتسمت بتذبذب كبير حيث بلغت حو الى 24.6 ألف طن عــام 2005 بقيمــة تصــديرية حو الى 16.8 مليون دو لار، ثم استمرت بين الإرتفاع و الإنخفاض حتى وصلت لأفصى قيمة لها عام 2011 حيث بلغت حو الى 623 ألف طن بقيمة تصديرية حو الى 210 مليون دو لار ثم انخفضت إلى لى 124 ألف طن بقيمة 240.6 مليون دولار عام 2015.

\section{الأهمية الاقتصادية للمبيدات الزراعية}

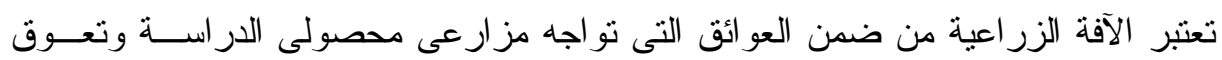

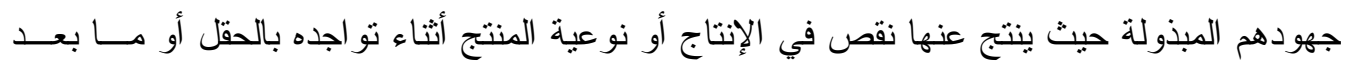

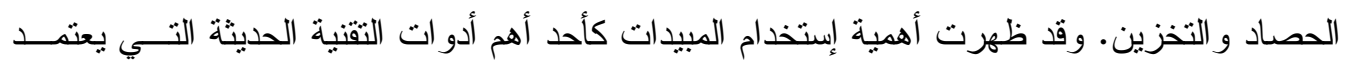

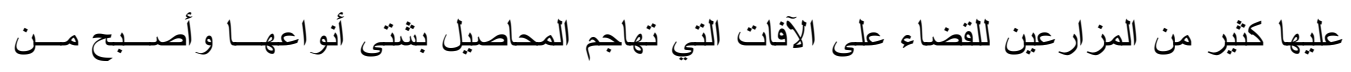

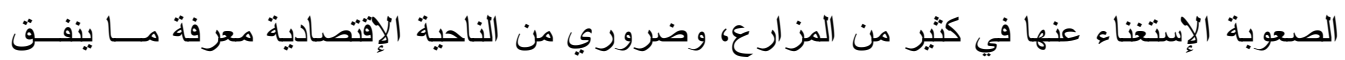
على مقاومة الآفات و المبيدات، وذللك على مستوى المز ارئاء ع و الدولة.

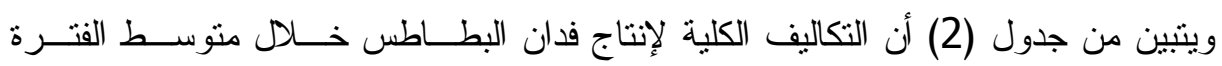
(2011-2015) بلغت حو الى 9050.1 جنية /فدان تقريباً وذلك كمتوسط عروتى الصيفى و النيلى،

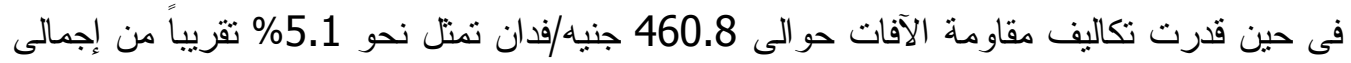
التكاليف، وقدرت قيمة المبيدات المستخدمة بحو الى 239.1 جنيه /فدان مثلت نحو 2.6\% تقرية

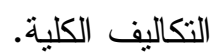

فى حين تبين أن التكاليف الكلية لإنتاج فدان من العنب خلال متوسط نفس الفترة بلغ حوالى الى 17566.2 جنيه /فدان وذللك كمتوسط لداخل وخارج الو ادى، فى حين قدرت تكاليف مكافحة الآفات

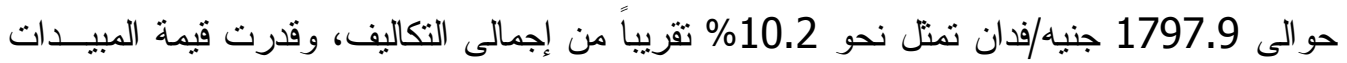

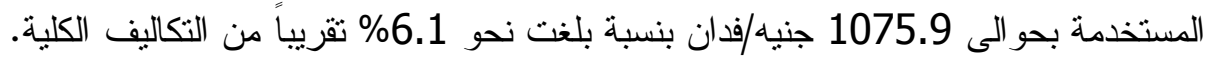




\section{جدول (2)}

التكاليف الكلية وتكاليف مقاومة الآفات وسعر المبيدات لمحصولى البطاطس والعب

خلا الفترة (2015-2011)

\begin{tabular}{|c|c|c|c|c|c|c|c|c|c|c|c|c|}
\hline \multicolumn{4}{|c|}{ (مستلزمات الإتاج) } & \multicolumn{4}{|c|}{ تكاليف مقاومة الآقات } & \multicolumn{4}{|c|}{ التكاليف الكلية (بالإيجار) } & \\
\hline \multicolumn{2}{|c|}{ العب } & \multicolumn{2}{|c|}{ البطاطس } & \multicolumn{2}{|c|}{ العب } & \multicolumn{2}{|c|}{ البطاطس } & \multicolumn{2}{|c|}{ الغب } & \multicolumn{2}{|c|}{ البطاطس } & \\
\hline خارج الو & الوادى & النيلى & الصيفى & خارج & الوادى & النيلى & الصيفى & خارج الواد & الوالى & النيلى النى & الصيفى & \\
\hline 650 & 1224 & 167 & 278 & 1410 & 1644 & 419 & 472 & 13189 & 14201 & 7317 & 10143 & 2011 \\
\hline 1335 & 1140 & 177 & 288 & 3095 & 1660 & 441 & 497 & 18980 & 17271 & 7429 & 11336 & 2012 \\
\hline 975 & 1180 & 186 & 287 & 1775 & 1860 & 550 & 491 & 18665 & 17799 & 8610 & 10989 & 2013 \\
\hline 975 & 1180 & 185 & 300 & 1655 & 1800 & 369 & 515 & 19331 & 18454 & 6247 & 11053 & 2014 \\
\hline 1000 & 1100 & 224 & 299 & 1680 & 1400 & 364 & 490 & 19935 & 17837 & 6289 & 11088 & 2015 \\
\hline 987 & 1164.8 & 187.8 & 290.4 & 1923 & 1672.8 & 428.6 & 493 & 18020 & 17112.4 & 7178.4 & 10922 & المتوسط \\
\hline
\end{tabular}

المصدر : وز ارة الزر اعة واستصلاح الأر اضي - قطاع الشئون الاقتصادية- الإدارة المركزية للإقتصاد الزر اعي و الإحصاء-نثرة الإقتصاد الزراعي-

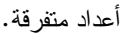

\section{التجارة الخارجية للمبيدات الزراعية}

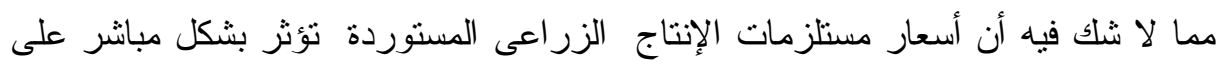

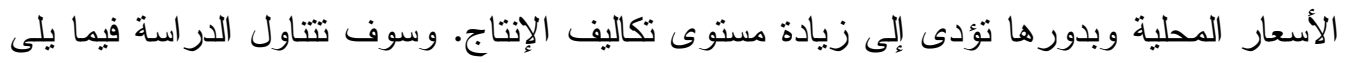

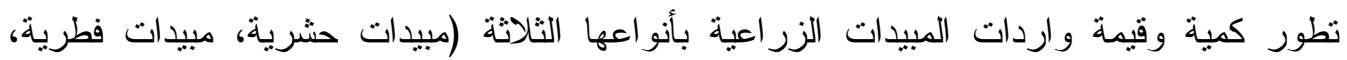
مبيدات حشائش)، ومعرفة ما ينفق عليها من عملة صعبة لاستير ادها سنوياً.

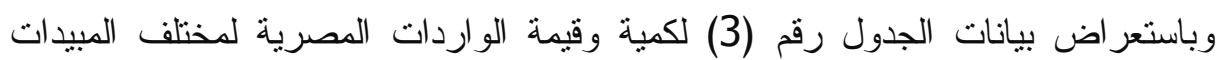

الزر اعية خلا الفترة (2015-2005) تبين أن منوسط إجمالي كمية الواردات للمبيدات الزراعية

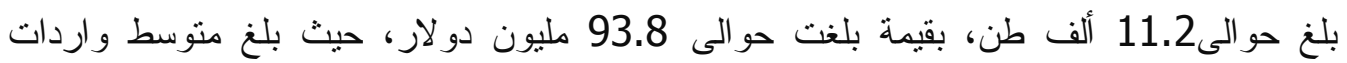
المبيدات الحشرية حو الى 4.3 ألف طن بما يعادل نحو 38.2\% تقريباً من إجمالي كمية واردات

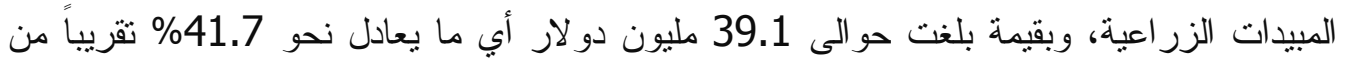
إجمالي قيمة الواردات من المبيدات الزراعية، في حين بلغ متوسط المبيدات الفطرية حوالى 4.6

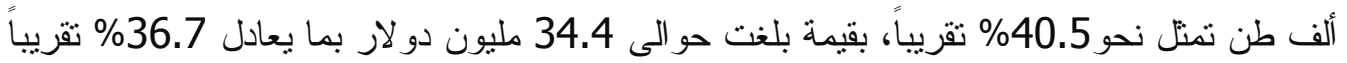

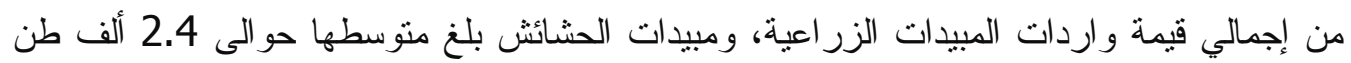

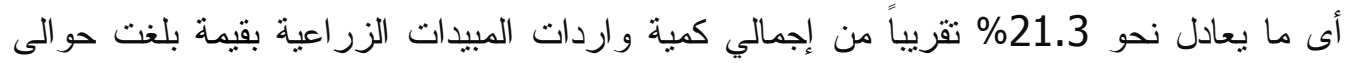
20.3 مليون دو لار بما يعادل 21.6\% نقريباً من إجمالي قيمة واردات المبيدات الزر اعية. 
جدول (3)

كمية وقيمة الواردات المصرية من مختلف المبيدات الزراعية

خلا الفترة (2015-2005)

\begin{tabular}{|c|c|c|c|c|c|c|c|c|}
\hline \multicolumn{2}{|c|}{ إجمالي } & \multicolumn{3}{|c|}{ قيمة الواردات (مليون دولار) } & \multicolumn{3}{|c|}{ كمية الواردات (بالألف طن) } & \multirow{2}{*}{ السنوات السن } \\
\hline القيمة & الكمية & الحشائش & الفطرية & الحشرية & الحشائش & الفطرية & الحشرية & \\
\hline 27.4 & 5.5 & 5.6 & 5.6 & 16.2 & 0.9 & 1.1 & 3.5 & 2005 \\
\hline 65.1 & 9.8 & 10.8 & 21.8 & 32.5 & 1.8 & 3.1 & 4.9 & 2006 \\
\hline 74.6 & 9.1 & 9.9 & 23.6 & 41.1 & 1.76 & 2.6 & 4.8 & 2007 \\
\hline 70.6 & 9.5 & 15.9 & 20.9 & 33.8 & 2.1 & 3.9 & 3.6 & 2008 \\
\hline 79.9 & 9.0 & 20.2 & 23.6 & 36.1 & 2.5 & 3.2 & 3.3 & 2009 \\
\hline 122.5 & 11.6 & 43.3 & 35.9 & 43.4 & 2.9 & 4.3 & 4.4 & 2010 \\
\hline 120.9 & 12.9 & 18.2 & 47.0 & 55.8 & 2.5 & 5.3 & 5.1 & 2011 \\
\hline 125.0 & 14.0 & 24.6 & 44.7 & 55.7 & 2.8 & 6.4 & 4.8 & 2012 \\
\hline 106.9 & 13.7 & 24.5 & 42.3 & 40.1 & 3.5 & 5.9 & 4.2 & 2013 \\
\hline 100.7 & 11.4 & 19.7 & 48.9 & 32.0 & 2.3 & 6.0 & 3.1 & 2014 \\
\hline 138.1 & 17.2 & 30.3 & 64.1 & 43.7 & 3.4 & 8.3 & 5.5 & 2015 \\
\hline 93.8 & 11.2 & 20.3 & 34.4 & 39.1 & 2.4 & 4.6 & 4.3 & المنوسط \\
\hline
\end{tabular}

المصدر: وزارة الزراعة واستصلاح الأراضي -فطاع الشئون الاقتصادية -الإدارة المركزية للاقتصاد الزراعي والإحصاء- لجنة مبيدات الآفات الزر اعية- أعداد متفرقة.

ومن المعادلة رقم (1) بالجدول (4) اتضح أن إجمالى الواردات من المبيدات الحشرية خلال

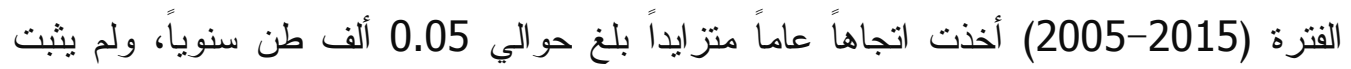
معنوية هذا التز ايد إحصائياً.

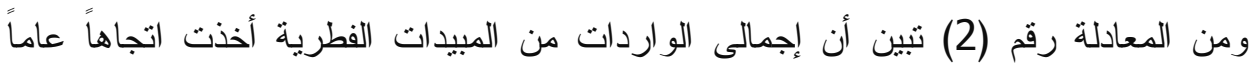

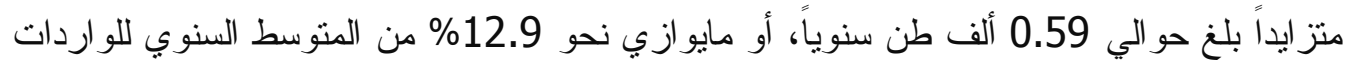

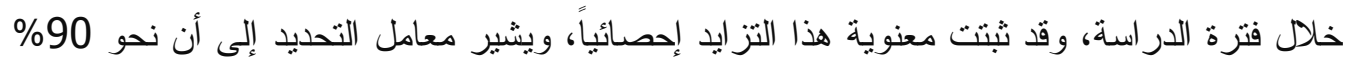

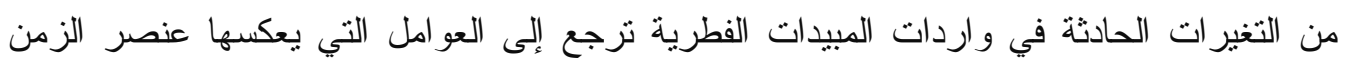
و الباقي يرجع إلى عو امل غير مقيسة.

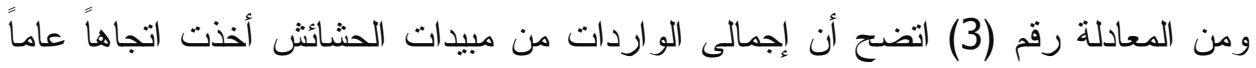

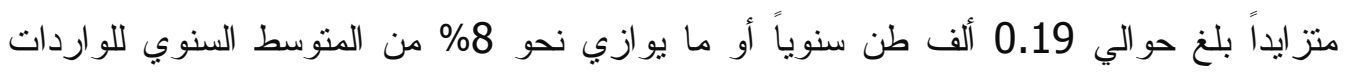

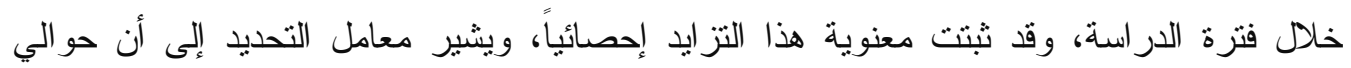

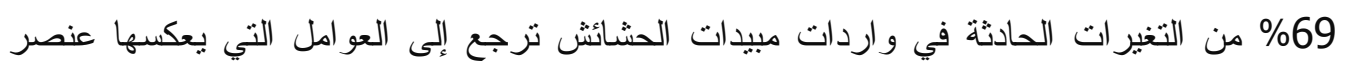
الزمن و الباقي يرجع إلى عو امل غير مدروسة. 
جدول (4)

معادلات الاتجاه الزمني العام لتطور واردات المبيدات الزراعية لمصر

خلا الفترة (2015-2005)

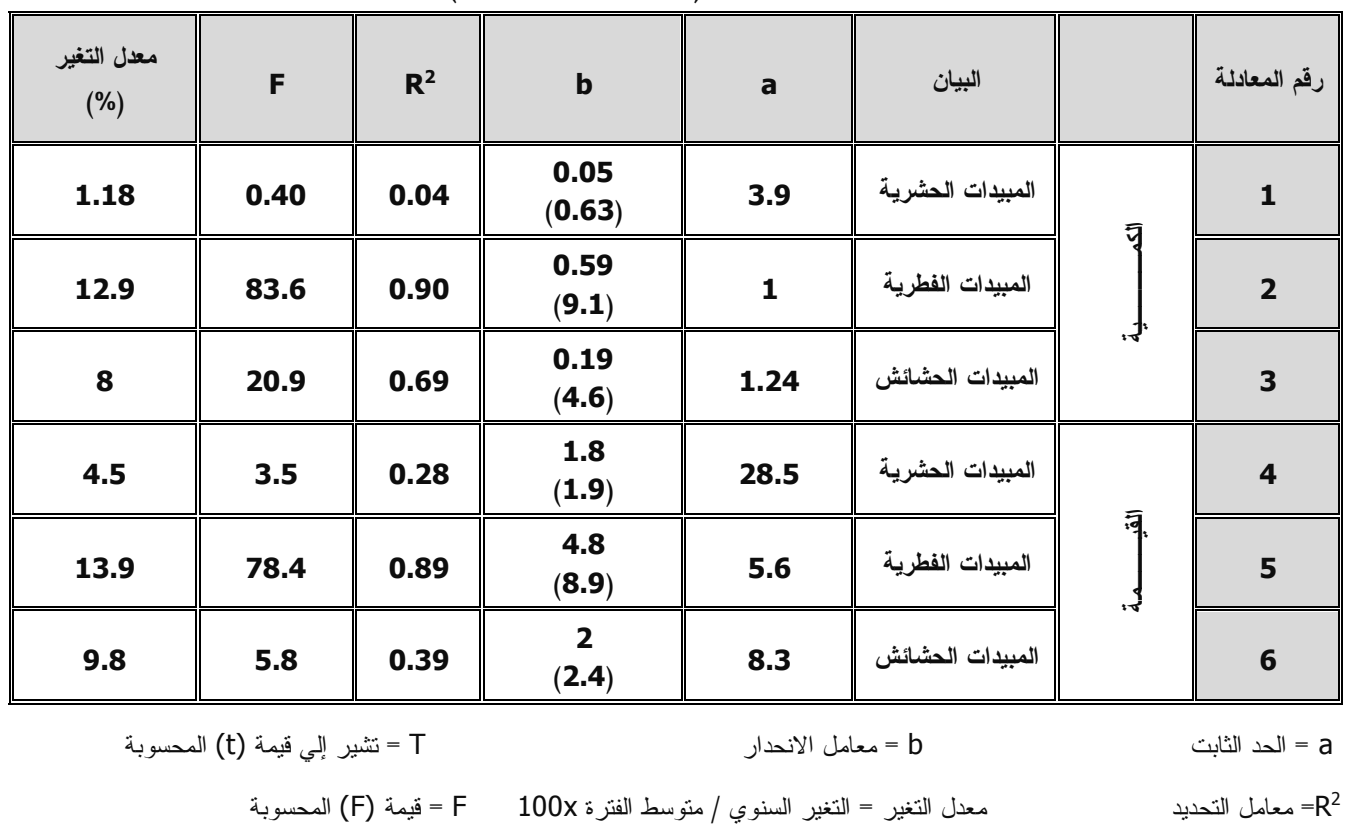

المصدر : جمعت وحسبت من الجدول رقم (3).

ومن المعادلة رقم (4) تبين أن قيمة الواردات من المبيدات الحشرية خلال الفترة (2005-

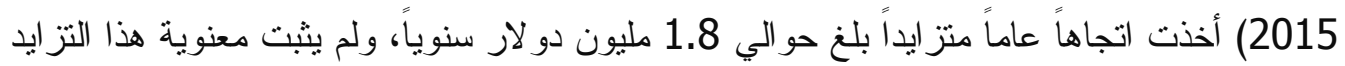
إحصائياً.

ومن المعادلة رقم (5) بنفس الجدول انضح أن قيمة الواردات من المبيدات الفطرية أخذت

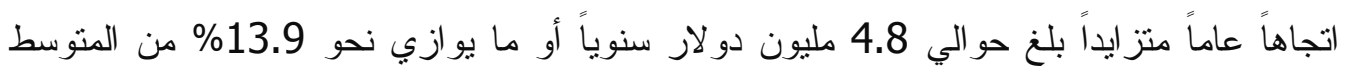

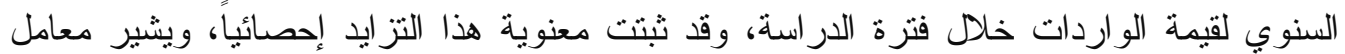

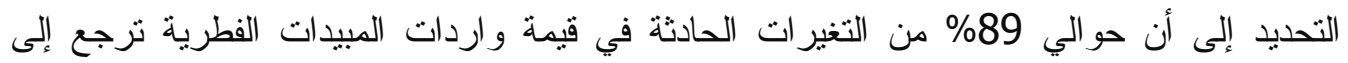

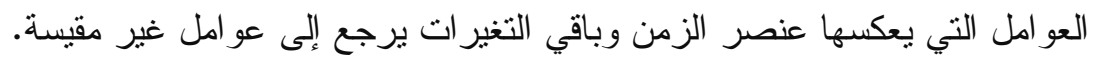

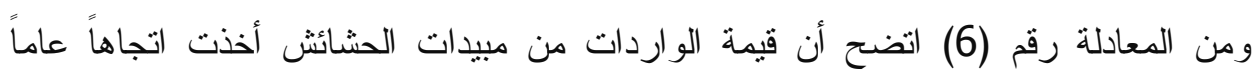

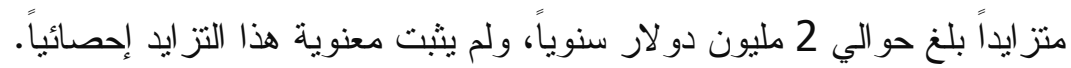
تحليل متبقيات المبيدات في محصولي الدراسة:

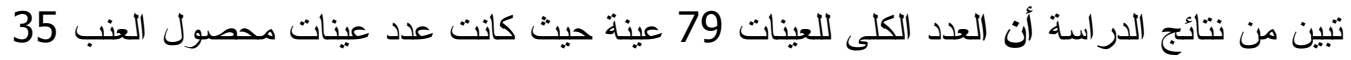

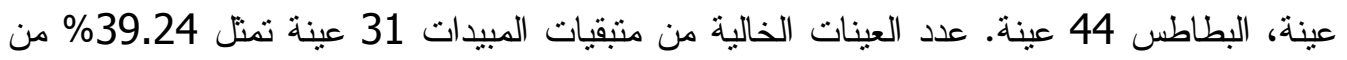

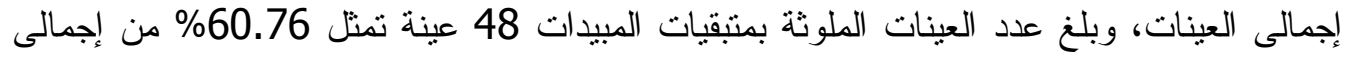

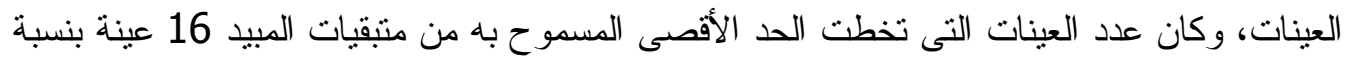
33.3\% من إجمالى العينات الملوثة بمتقيات المبيدات و التى من الممكن أن يكون لها تأثير ات سلبية

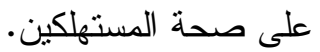




$$
1 \text { - تقصى متبقيات المبيدات فى البطاطس والعنب: }
$$

أ- تقصي متبقيات المبيدات في البطاطس: أظهرت النتائج بالجدول (5) أن عدد 17 عينة تمنل

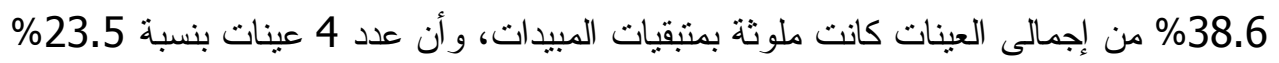
من إجمالي العينات الملوثة قد احتوت على متنقيات مبيدات أعلى من الحد الأقصى المسموح باه، و التى من الممكن أن يكون لها تأثثرات سلبية على صحة المستهلكين، في حين أن 27 عينة

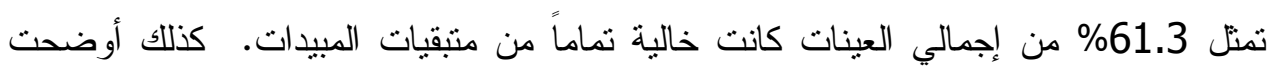
نتائج الدراسة وجود 24 منبقي مبيد مختلف في عينات البطاطس وجد بعضها أكثر من مرة

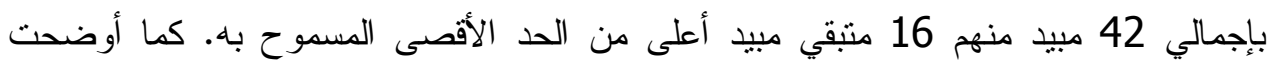

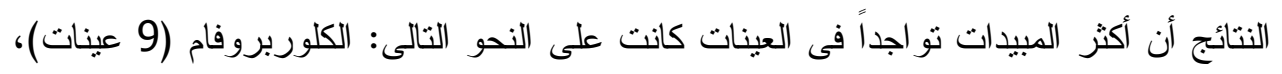
الكلور بيريفوس (4 عينات)، فينتويت (4 عينات)، ثم الكبريت (4 عينات). كما تنين من نتائج

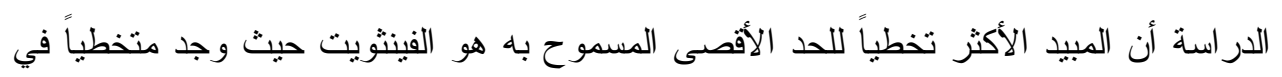

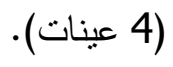

جدول (5) متبقيات المبيدات التى وجدت فى عينات محصول البطاطس التى تم جمعها من

\begin{tabular}{|c|c|c|c|c|c|c|c|c|c|c|}
\hline \multicolumn{2}{|c|}{ العبات العلوثة } & \multirow[t]{2}{*}{ العبيد } & \multirow[t]{2}{*}{ أقلى تركيز } & \multirow[t]{2}{*}{ أعلى تركيز } & \multirow[t]{2}{*}{ لتركيز } & \multirow[t]{2}{*}{ علد البيا فن تكرل } & \multirow[t]{2}{*}{ الدا الأصصى المسموح } & \multirow[t]{2}{*}{ تلتالة بوميأ سن } & \multicolumn{2}{|c|}{ 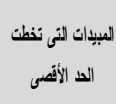 } \\
\hline$\%$ & لـ & & & & & & & & عند & $\%$ \\
\hline \multirow{24}{*}{$\begin{array}{c}38.6 \\
\%\end{array}$} & \multirow{24}{*}{$\begin{array}{l}1 \\
7\end{array}$} & Acetamiprid & $\angle L O Q$ & $\angle L O Q$ & $\angle L O Q$ & 1 & 0.01 & 0.0700 & & \\
\hline & & "alpha-HCH & 0.29 & 0.29 & 0.29 & 1 & № MRL & № ADI & 1 & 100 \\
\hline & & "beta-HCH & 0.21 & 0.21 & 0.21 & 1 & № MRL & No ADI & 1 & 100 \\
\hline & & Carbendazim & 0.89 & 0.89 & 0.89 & 1 & 0.1 & 0.0200 & 1 & 100 \\
\hline & & Carbofuran & 1.66 & 1.66 & 1.66 & 1 & 0.001 & 0.0002 & 1 & 100 \\
\hline & & Chlorpropham & 0.01 & 4.06 & 1.368 & 9 & 30 & 0.0500 & & 0 \\
\hline & & Chlorpyrifos & $\angle L O Q$ & 1.1 & 0.282 & 4 & 2 & 0.0010 & & 0 \\
\hline & & •delta-HCH & 0.1 & 0.1 & 0.1 & 1 & No MRL & No ADI & 1 & 100 \\
\hline & & Diazinon & 0.33 & 0.33 & 0.33 & 1 & 0.01 & 0.0002 & 1 & 100 \\
\hline & & Dimethoate & 0.14 & 0.14 & 0.14 & 1 & 0.05 & 0.0010 & 1 & 100 \\
\hline & & Fenhexamid & 0.02 & 0.02 & 0.02 & 1 & 0.01 & 0.2000 & 1 & 100 \\
\hline & & $\begin{array}{l}\text { Fludioxonil } \\
\end{array}$ & $\angle L O Q$ & $\angle L O Q$ & $\angle L Q Q$ & 1 & 5 & 0.3700 & & 0 \\
\hline & & "Gamma-HCH & 0.26 & 0.26 & 0.26 & 1 & No MRL & No ADI & & 0 \\
\hline & & Imazalil & $\angle L O Q$ & $\angle L O Q$ & $\angle L Q Q$ & 1 & 5 & 0.0250 & 1 & 100 \\
\hline & & Metalaxyl & $\angle \angle 0 Q$ & 0.02 & 0.01 & 2 & 0.05 & 0.0800 & & 0 \\
\hline & & Myclobutanil & 0.03 & 0.03 & 0.03 & 1 & 0.06 & 0.0250 & & 0 \\
\hline & & Omethoate & 0.07 & 0.07 & 0.07 & 1 & 0.05 & 0.0003 & 1 & 100 \\
\hline & & Ortho-Phenyl Phenol(opp) & 0.01 & 0.01 & 0.01 & 1 & 0.05 & 0.4000 & & 0 \\
\hline & & $p, p-D D D$ & 0.02 & 0.02 & 0.02 & 1 & 0.05 & 0.0100 & 1 & 100 \\
\hline & & ${ }^{n} \mathrm{p}, \mathrm{p}$-DDT & 0.01 & 0.01 & 0.01 & 1 & 0.05 & 0.0100 & 1 & 100 \\
\hline & & "Phenthoate & $<\angle 0 Q$ & 0.27 & 0.07 & 4 & № MRL & 0.0030 & 4 & 100 \\
\hline & & Propamocarb & 0.01 & 0.01 & 0.01 & 1 & 0.3 & 0.2900 & & 0 \\
\hline & & Sulfur & 0.1 & 0.13 & 0.115 & 4 & NO MRL & No ADI & & 0 \\
\hline & & Thiabendazole & 0.01 & 0.01 & 0.01 & 1 & 15 & 0.1 & & 0 \\
\hline
\end{tabular}

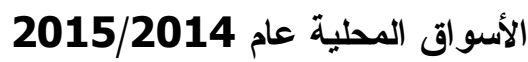

المصدر : جمعت وحسبت من نتائج عينة الدراسة. (*) مبيدات ممنوع استخدامها، LOQ: حد القياس و التي كانت عند (0.01) ملجم/كجم '1 ، MRL: الحد الأقصى المسموح به للمتبقي وفقا لهيئة الدستور الغذائي (منظمة الأغذية و الزر اعة / منظمة الصحة العالمية ، 2004). 
ب- تقصي متبقيات المبيدات في العنب: أظهرت النتائج بالجدول (6) أن عدد 31 عينة تمثل

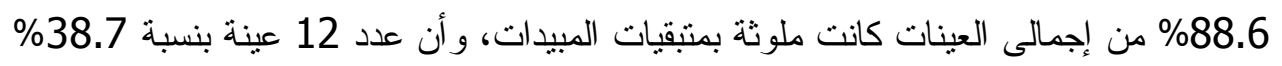
من إجمالي العينات الملوثة قد احتوت على متبقيات مبيدات أعلى من الحد الأقصى المسموح

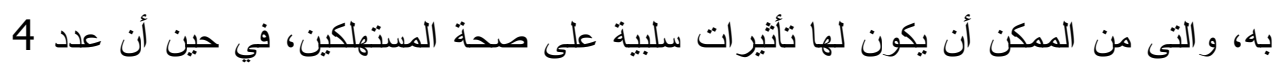

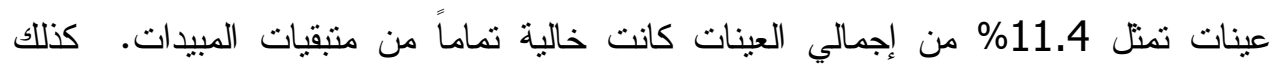

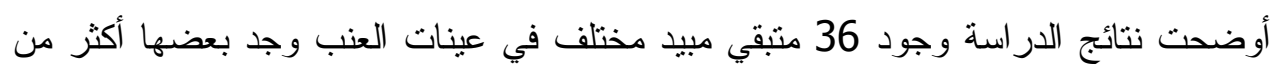

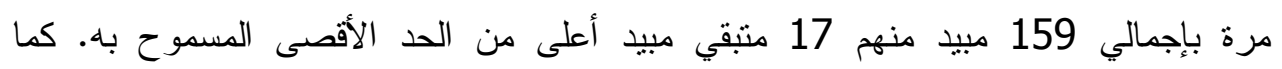
أوضحت النتائج أن أكثر المبيدات تكرارًا فيى العينات كانت على النى النحو التالى: الكاربندازيم (19 عينة)، يليه الكلوربيريفوس (17 عينة)، ثم اللامبدا ثيهالوثرين (17 عينة)، يليه الثيوفينات

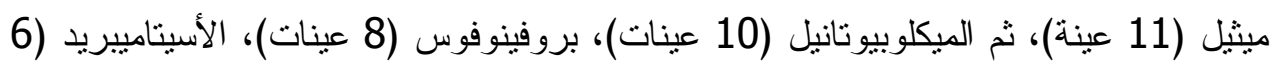

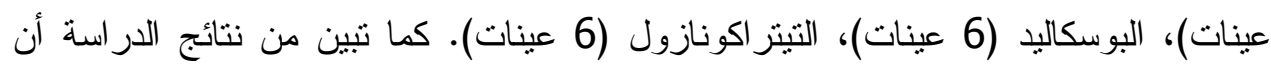

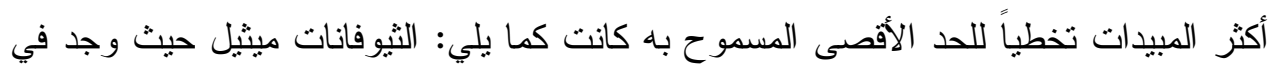
(5 عينات)، تلاه البروفينوفوس في (4 عينات)، ثم الأوميثويت وجد في ( 3 عينات) ويليه

$$
\text { الدايمثويت في (3 عينات). }
$$

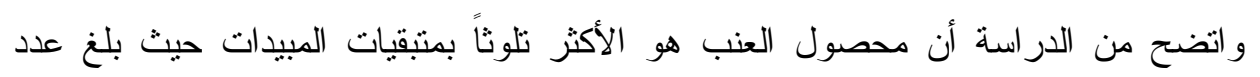

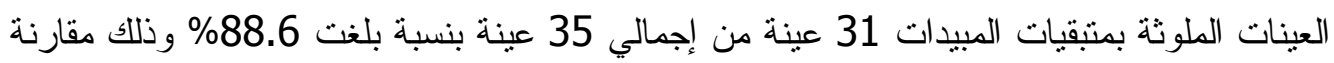

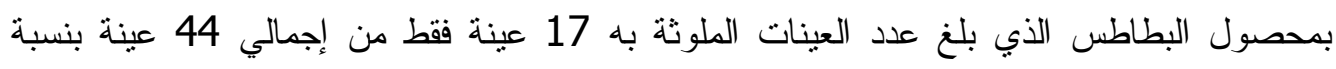

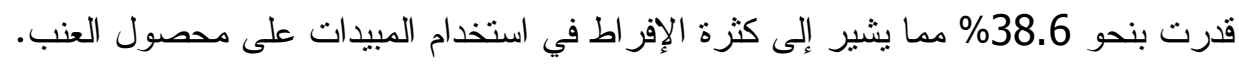

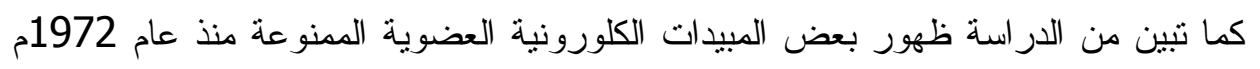

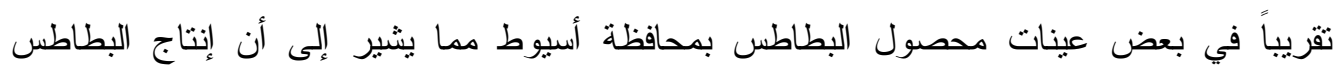

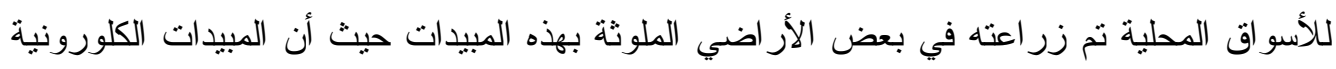
العضوية من الملوثات العضوية الثابتة والتي يطول فترة بقائها بالتربة لفترة تصل الإلى أكثر من 50

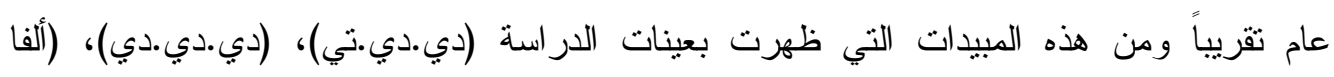
إتش1)، (بيتا إتش سي إنش)، (دلتا إتش سي إنش)، كما وجد منتقي مبيد الفينتويت وهو أحد

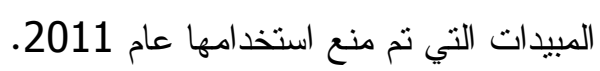

ونتير النتائج من الناحية الإقتصادية إلى قيام منتجي محصول العنب بإهدار كبير في المبيدات

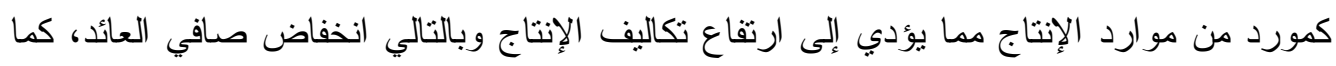
أن 38.7\% من إجمالي العينات الملوثة بالعنب متخطية للحد الأقصى المسموح به لمتنقيات المبيدات

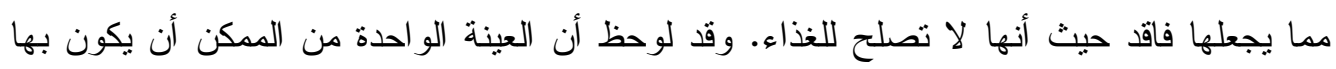

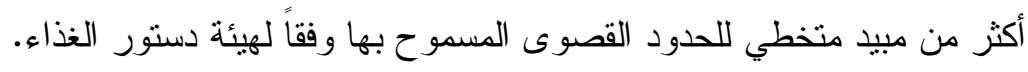


جدول (6) - (6)

متبقيات المبيدات التى وجدت فى عينات محصول العنب التى تم جمعها من الأسواق المحلية

عام 2015/2014

\begin{tabular}{|c|c|c|c|c|c|c|c|c|c|c|}
\hline \multicolumn{2}{|c|}{ العينات اللموثة } & \multirow[t]{2}{*}{ المبيا } & \multirow[t]{2}{*}{ تركيز } & \multirow[t]{2}{*}{ أعلى تركيز } & \multirow[t]{2}{*}{ التركيز } & \multirow[t]{2}{*}{ تكرار المبيد } & \multirow[t]{2}{*}{ المسموح } & \multirow[t]{2}{*}{ تلتولة المسموح } & \multicolumn{2}{|c|}{ 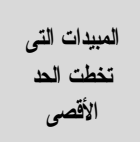 } \\
\hline$\%$ & العلد & & & & & & & & عدد & $\%$ \\
\hline \multirow{36}{*}{$\% 88.6$} & & Acetamiprid & $\begin{array}{c}<\mathrm{LO} 0 \\
\mathrm{Q}\end{array}$ & 0.11 & 0.033 & 6 & 0.5 & 0.07 & 0 & 0.0 \\
\hline & & Azoxystrobin & $\begin{array}{l}<\mathrm{LO} \\
0\end{array}$ & 0.04 & 0.02 & 2 & 2 & 0.2 & 0 & 0.0 \\
\hline & & Boscalid & 0.05 & 0.26 & 0.135 & 6 & 5 & $\overline{0.04}$ & 0 & 0.0 \\
\hline & & Bromuconazole & 0.01 & 0.01 & 0.01 & 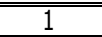 & 0.5 & 0.01 & 0 & 0.0 \\
\hline & & Carbendazim & $\overline{0.01}$ & $\overline{c 1.11}$ & 0.325 & $\overline{19}$ & 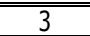 & 0.02 & 0 & 0.0 \\
\hline & & Chlorpyrifos & $\begin{array}{c}<\mathrm{LO} \\
0\end{array}$ & 0.16 & 0.032 & 17 & 0.5 & 0.001 & 0 & 0.0 \\
\hline & & Coumatetralyl & 0.01 & 0.01 & 0.01 & 1 & No MRL & No ADI & 0 & 0.0 \\
\hline & & Cyflufenamide & $\overline{0.01}$ & 0.01 & 0.01 & $\overline{11}$ & 0.15 & 0.04 & 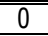 & 0.0 \\
\hline & & Cyfluthrin & 0.01 & 0.01 & 0.01 & 1 & 0.3 & 0.003 & 0 & 0.0 \\
\hline & & Cypermethrin & 0.01 & 0.04 & 0.023 & 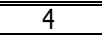 & 0.2 & 0.05 & $\overline{00}$ & 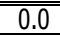 \\
\hline & & Cyprodinil & $\overline{0.02}$ & $\overline{c 1.06}$ & $\overline{0.373}$ & $\overline{3}$ & 3 & 0.03 & $\overline{00}$ & 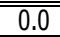 \\
\hline & & Diazinon & 0.01 & 0.01 & 0.01 & 1 & 0.01 & 0.0002 & 0 & 0.0 \\
\hline & & Difenoconazole & 0.02 & 0.02 & 0.02 & 1 & 3 & 0.01 & 0 & 0.0 \\
\hline & & Dimethoate & $\begin{array}{c}<\mathrm{LO} \\
\mathrm{Q}\end{array}$ & 0.14 & 0.048 & 4 & 0.02 & 0.001 & 3 & 75.0 \\
\hline & & Fenhexamid & 0.02 & 0.02 & 0.02 & 1 & 15 & 0.2 & 0 & 0.0 \\
\hline & & Fenpropathrin & 0.07 & 0.07 & 0.07 & 1 & 0.01 & 0.03 & 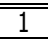 & 100.0 \\
\hline & & Fludioxonil & $\begin{array}{c}<\mathrm{LO} \\
Q\end{array}$ & 1.3 & 0.333 & 4 & 2 & 0.37 & 0 & 0.0 \\
\hline & & Flusilazole & $<\mathrm{LO}$ & 0.02 & 0.005 & 4 & 0.2 & 0.002 & 0 & 0.0 \\
\hline & & Flutolanil & 0.01 & $\overline{0.01}$ & 0.01 & $\overline{11}$ & 0.01 & 0.09 & 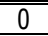 & 0.0 \\
\hline & 31 & Imidacloprid & $\begin{array}{c}<\mathrm{LO} \\
\mathrm{Q}\end{array}$ & 0.02 & 0.01 & 4 & 1 & 0.06 & 0 & 0.0 \\
\hline & & Iprodione & $\begin{array}{c}<\mathrm{LO} \\
\mathrm{Q}\end{array}$ & $<\mathrm{LOQ}$ & $<\mathrm{LOQ}$ & 1 & 10 & 0.06 & 0 & 0.0 \\
\hline & & Kresoxim-methyl & $\begin{array}{c}<\mathrm{LO} \\
\mathrm{Q}\end{array}$ & $<\mathrm{LOQ}$ & $<L O Q$ & 1 & 1 & 0.4 & 0 & 0.0 \\
\hline & & $\begin{array}{c}\text { Lambda- } \\
\text { Cyhalothrin }\end{array}$ & $\begin{array}{c}<\mathrm{LO} \\
\mathrm{Q}\end{array}$ & 0.24 & 0.039 & 17 & 0.2 & 0.0025 & 1 & 5.9 \\
\hline & & Malaoxon & 0.01 & 0.01 & 0.01 & 1 & $\overline{5}$ & 0.03 & 0 & $\overline{0.0}$ \\
\hline & & Malathion & 0.01 & 0.03 & 0.02 & 2 & & & 0 & 0.0 \\
\hline & & $\begin{array}{l}\text { Metalaxyl } \\
\end{array}$ & 0.05 & 0.05 & 0.05 & 1 & $\overline{11}$ & $\overline{0.08}$ & 0 & 0.0 \\
\hline & & Myclobutanil & $\begin{array}{c}<\mathrm{LO} \\
Q\end{array}$ & 0.03 & 0.014 & 10 & 0.9 & 0.025 & 0 & 0.0 \\
\hline & & Omethoate & 0.01 & 0.07 & 0.032 & 5 & 0.02 & 0.0003 & 3 & 60.0 \\
\hline & & Oxamyl & $\begin{array}{c}<\mathrm{LO} \\
\mathrm{Q}\end{array}$ & $<\mathrm{LOQ}$ & $<\mathrm{LOQ}$ & 1 & 0.01 & 0.001 & 0 & 0.0 \\
\hline & & Penconazole & $\begin{array}{c}<\mathrm{LO} \\
\mathrm{Q}\end{array}$ & 0.01 & 0.003 & 3 & 0.2 & 0.03 & 0 & 0.0 \\
\hline & & Profenofos & 0.01 & 0.12 & 0.039 & 8 & 0.01 & 0.03 & 4 & 50.0 \\
\hline & & Propiconazol & $\begin{array}{c}<\mathrm{LO} \\
\mathrm{Q}\end{array}$ & 0.02 & 0.005 & 4 & 0.3 & 0.04 & 0 & 0.0 \\
\hline & & Proquinazid & 0.01 & 0.01 & 0.01 & 1 & 0.5 & 0.01 & 0 & 0.0 \\
\hline & & Pyraclostrobin & $\begin{array}{c}<\mathrm{LO} \\
\mathrm{Q} \\
\end{array}$ & 0.08 & 0.018 & 5 & 2 & 0.03 & 0 & 0.0 \\
\hline & & Tetraconazole & $\begin{array}{c}<\mathrm{LO} \\
\mathrm{Q} \\
\end{array}$ & 0.02 & 0.013 & 6 & 0.5 & 0.004 & 0 & 0.0 \\
\hline & & $\begin{array}{c}\text { Thiophanate- } \\
\text { methyl }\end{array}$ & $\begin{array}{c}<\mathrm{LO} \\
\mathrm{Q} \\
\end{array}$ & 1.56 & 0.35 & 11 & 0.1 & 0.08 & 5 & 45.5 \\
\hline
\end{tabular}

المصدر : جمعت وحسبت من نتائج عينة الدراسة. LOQ: حد القياس و التي كانت عند (0.01) ملجم/كجم "1-، MRL: الحد الأقصى المسموح به للمتثقي 
2- تحليل المخاطر الصحية المحتملة والمرتبطة بالتعرض لمتبقيات المبيدات التى تخطت الحد

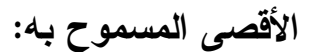

يتم حساب المتتاول اليومى المحسوب Estimated Daily Intake (EDI) للمبيدات التى تخطت الحد الأقصى المسموح به Maximum Residue Limit (MRL) فى كل محصول عن طريق ضرب

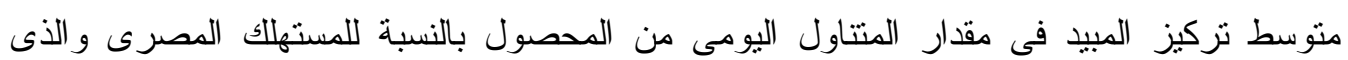

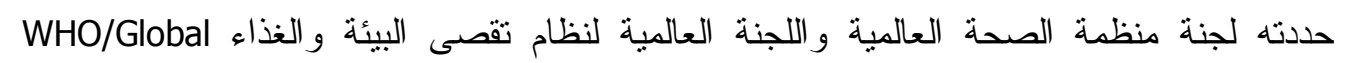
Environment Monitoring System-Food (WHO/GEMS/FOODS, 2006) الغذائى لمصر ضمن الفئة C. و يتم حساب مؤشر الخطر عن طريق قسمة المتتاول اليومى المحسوب لكل مبيد على المقدار المقبول تتاولة يوميا

المبيد و الذى وضعته هيئة سلامة الغذاء الأوروبية European Food Safety Authority (EFSA) المتناول اليومى المحسوب (ملجم/كجم من وزن الجسم)= منتوسط وزن الفرد (60 كجم) × 1000

فى هذا البحث نم تحليل المخاطر الصحية الناتجة عن استهلاك الإنسان للغذاء الملوث بمتقبات المبيدات بكميات تخطت الحدود المسموح بها بومياً وذذك عن طريق حساب مؤشرات الخطر لهذه المبيدات. وذلك من خلال حساب مقدار المتتاول اليومى من المبيد على سلعة ما باليا

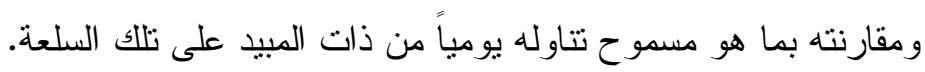

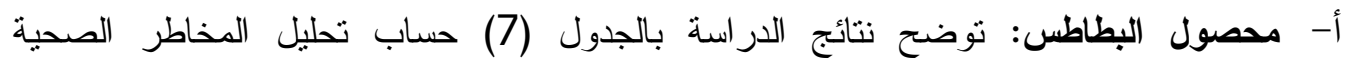

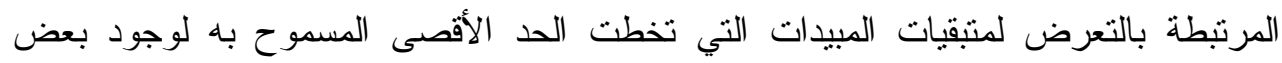

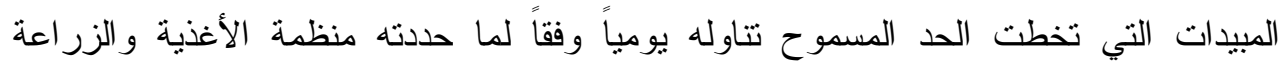
ومنظمة الصحة العالمية وهي: الكاربوفيوران بمؤشر خطورة قدر بنحو 1128\% بأي وني بنسبة

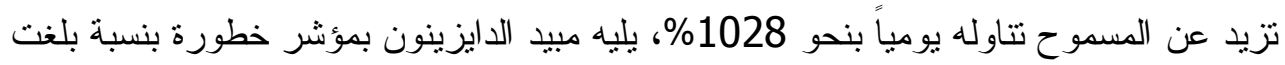

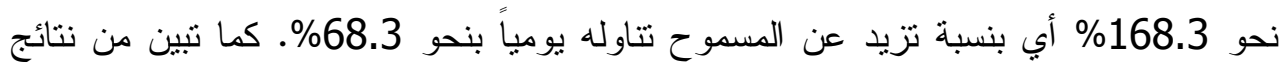

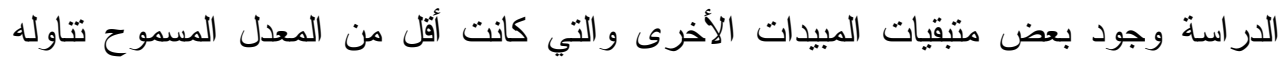

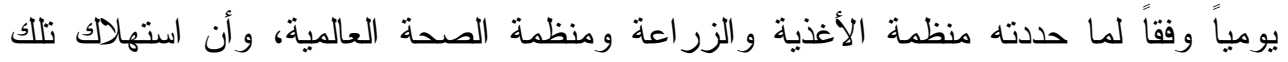

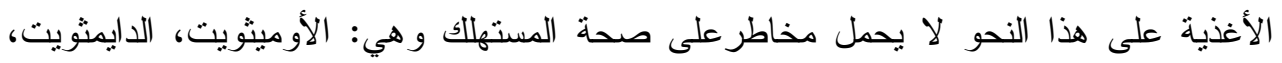

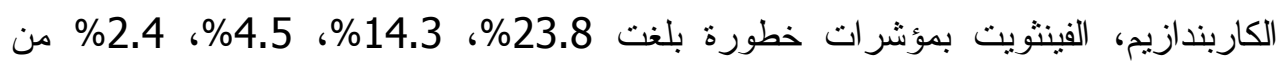
المقدار المقبول تتاوله يومياً على الترتيب. 


\section{جدول (7)}

\section{المتناول اليومى المحسوب للمبيدات التى تخطت الحد الأقصى المسموح به}

في عينات البطاطس عام 2015/2014

\begin{tabular}{|c|c|c|c|c|c|c|}
\hline الأقصيى المسموح به المتخطية للد & البطاطس عن طريق المستهلئ المصرى اليومى المخص & متركيز & 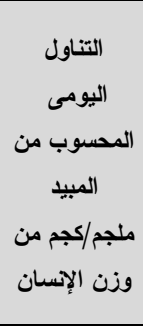 & 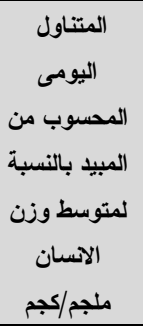 & تلناله المسموح الأقصى & المنسبة المتنوب من المبيد المقاول \\
\hline alpha-HCH & 61.2 & 0.29 & 17.7 & 0.0003 & & \\
\hline beta-HCH & 61.2 & 0.21 & 12.9 & 0.0002 & & \\
\hline delta-HCH & 61.2 & 0.1 & 6.1 & 0.0001 & & \\
\hline Carbendazim & 61.2 & 0.89 & 54.5 & 0.0009 & 0.02 & 4.5 \\
\hline Carbofuran & 61.2 & 1.66 & 101.6 & 0.0017 & 0.0002 & 1128.8 \\
\hline Diazinon & 61.2 & 0.33 & 20.2 & 0.0003 & 0.0002 & 168.3 \\
\hline Dimethoate & 61.2 & 0.14 & 8.6 & 0.0001 & 0.001 & 14.3 \\
\hline Fenhexamid & 61.2 & 0.02 & 1.2 & 0.00002 & 0.2 & 0.01 \\
\hline Omethoate & 61.2 & 0.07 & 4.3 & 0.0001 & 0.0003 & 23.8 \\
\hline p,p-DDD & 61.2 & 0.02 & 1.2 & 0.00002 & 0.01 & 0.2 \\
\hline p,p-DDT & 61.2 & 0.01 & 0.6 & 0.00001 & 0.01 & 0.1 \\
\hline Phenthoate & 61.2 & 0.07 & 4.3 & 0.0001 & 0.003 & 2.4 \\
\hline
\end{tabular}

المصدر : جمعت وحسبت من نتائج عينة الدراسة.

ب- محصول العنب: نوضح نتائج الدراسة بالجدول (8) حساب تحليل المخاطر الصحية المرتبطة بالتعرض لمتبقيات المبيدات التي تخطت الحد الأقصى المسموح به أنها كانت أقل من المعدل

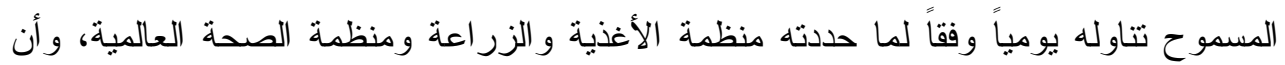
استهلاك تلك الأغذية على هذا النحو لا يحمل مخاطرعلى صحة المستهلك وهي: الأوميثويث،

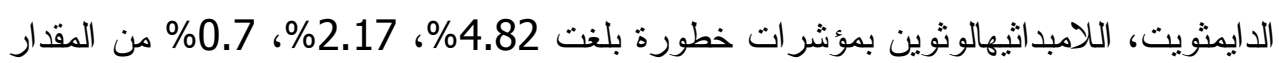

$$
\text { المقبول تتاوله يومياً على التزتيب. }
$$

و على الرغم من أن النتائج أظهرت أن المخاطر المرتبطة بالتعرض لمتبقيات المبيدات عن طريق المحاصيل الغذائية ضيئلة، إلا أنه يجب إتخاذ محاذير واحتياطات خاصنة بالتعرض مستقبلاً

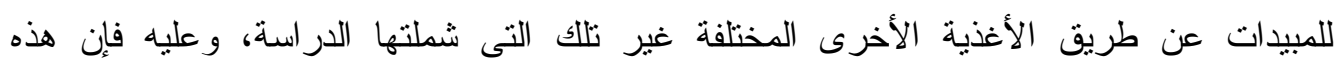
التقديرات للمتتاول اليومى لا تعتبر تقديرات كلية للمتتاول اليومى حيث إنها لم تشتنل على تقدير

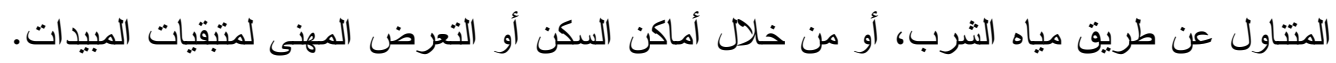

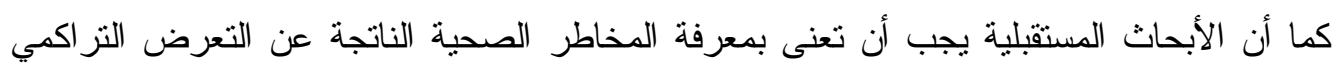
للعديد من متبقيات المبيدات، حيث نم حساب ذلك على أساس وجود المبيدات منفرده. 
جدول (8)

المتناول اليومى المحسوب للمبيدات التى تخطت الحد الأقصى المسموح به (8)

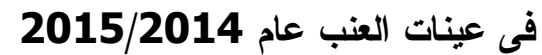

\begin{tabular}{|c|c|c|c|c|c|c|}
\hline المبيد الذى تخطى الدد الأقصى & 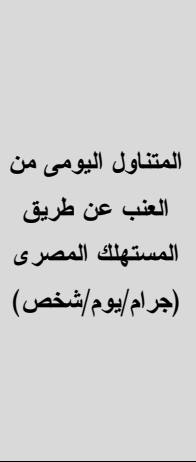 & متوسط & 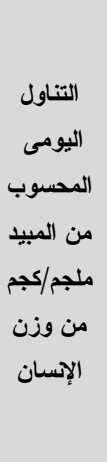 & 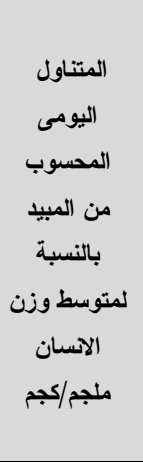 & لئل الأقصى الحسموح & 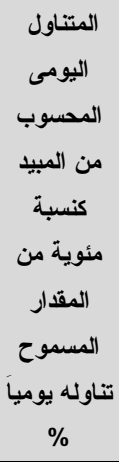 \\
\hline Dimethoate & 27.1 & 0.05 & 1.30 & 0.00002 & 0.001 & 2.17 \\
\hline Fenpropathrin & 27.1 & 0.07 & 1.90 & 0.00003 & 0.03 & 0.11 \\
\hline Lambda-Cyhalothrin & 27.1 & 0.04 & 1.06 & 0.00002 & 0.0025 & 0.70 \\
\hline Omethoate & 27.1 & 0.03 & 0.87 & 0.00001 & 0.0003 & 4.82 \\
\hline Profenofos & 27.1 & 0.04 & 1.06 & 0.00002 & 0.03 & 0.06 \\
\hline Thiophanate-methyl & 27.1 & 0.35 & 9.49 & 0.00016 & 0.08 & 0.20 \\
\hline
\end{tabular}

المصدر : جمعت وحسبت من نتائج عينة الدراسة.

3- نتائج محافظات عينة الدراسة (البطاطس و العنب):

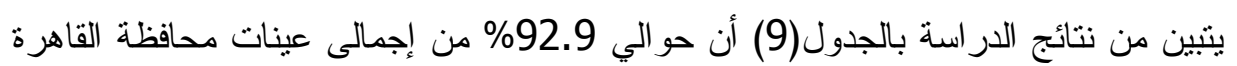

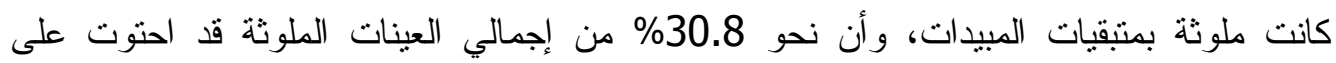

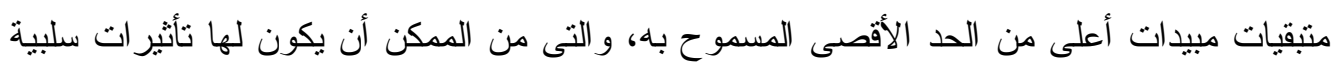
على صحة المستهكين، في حين أن 7.1\% فقط من إجمالي عينات هذه المحافظة كانت خالية تماماً

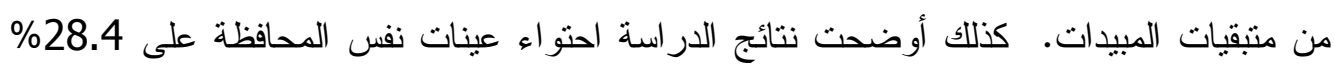

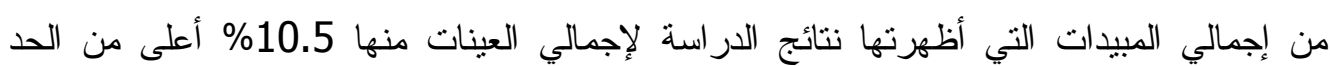

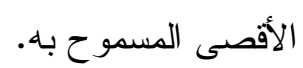

كما يوضح نفس الجدول أن60\% من إجمالى عينات محافظة المنوفية كانت ملوثة بمتبقيات

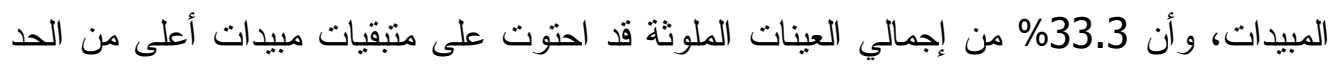

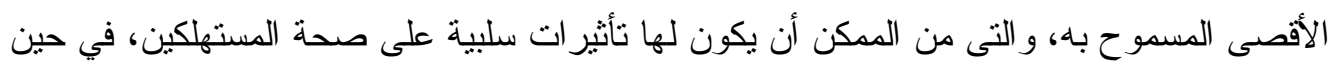

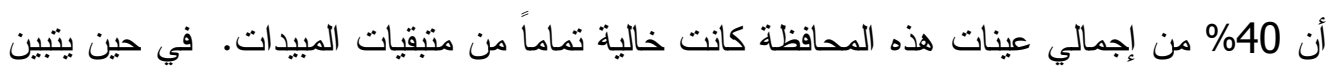

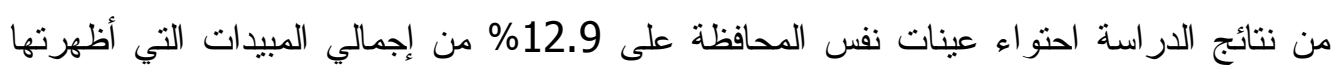

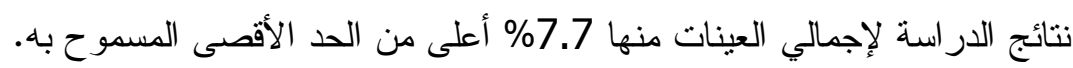

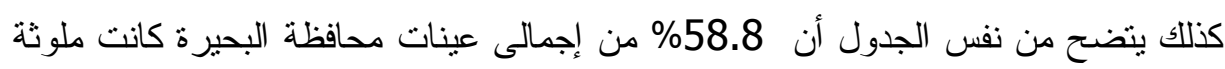

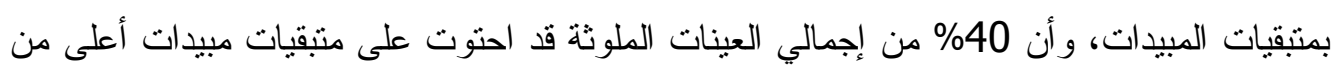

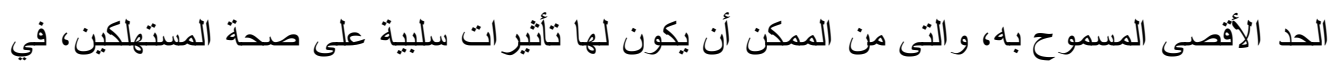

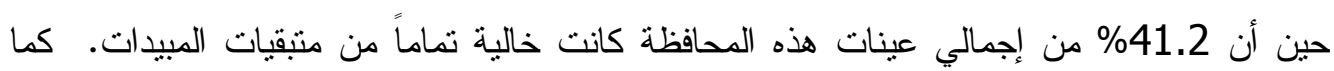


أوضحت نتائج الدراسة احتواء عينات نفس المحافظة على 17.4\% من إجمالي المبيدات التي أظهرتها نتائج الدراسة لإجمالي العينات منها 17.1\% أعلى من الحد الأقصى المسموح به. كما تبين من نفس الجدول أن 66.7\% من إجمالى عينات محافظة الاسماعيلية كانت ملوثة لـاته بمنقيات المبيدات، وأن 33.3\% من إجمالي العينات الملوثة قد احتوت على متثقيات مبيدات أعلى لفين

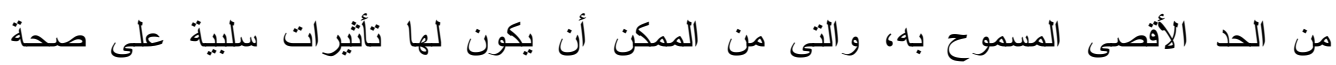

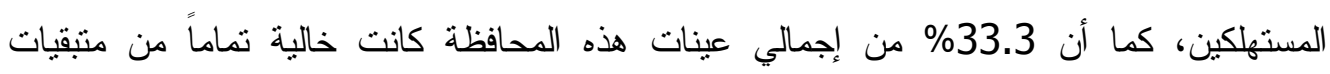
المبيدات. في حين ينبين من نتائج الدراسة احتو اء عينات نفس المحافظة على 11.4\% من عن إجمالي

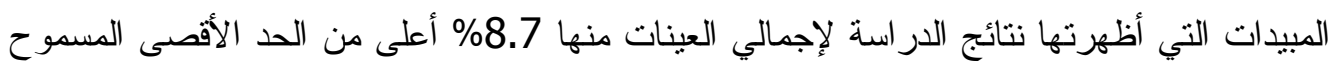

و أظهرت نتائج الدراسة من نفس الجدول أن محافظة المنيا قد احتوت على 43.8\% من إجمالى عيناتها كانت ملوثة بمتبقيات المبيدات، وأن 28.6\% من إجمالي العينات الملوثة قد احتوت

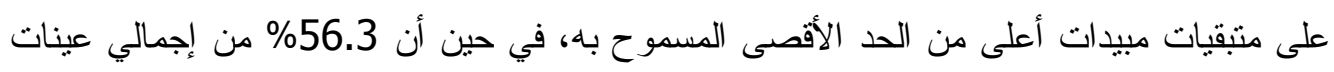

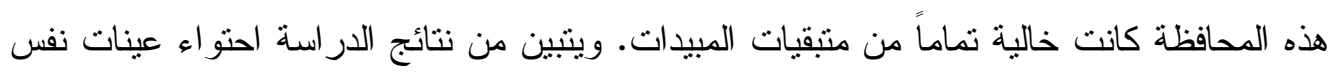

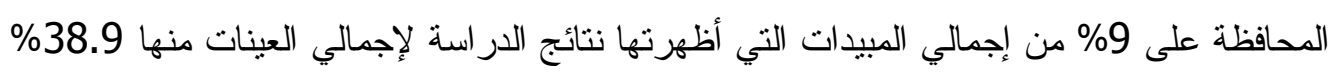
أعلى من الحد الأقصى المسموح به. أما محافظة أسيوط فقد أظهرت نتائج التحليل بذات الجدول أن 46.2\% من إهمالى عيناتها كانت ملوثة بمنبقيات المبيدات، وأن 33.3\% من إجمالي العينات الملوثة قد احتوت على متنقيات

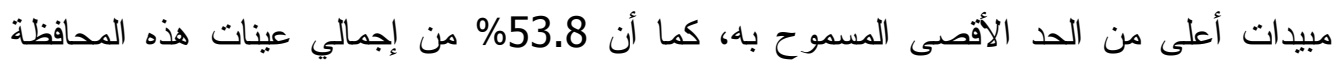

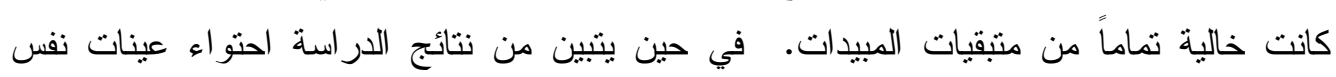

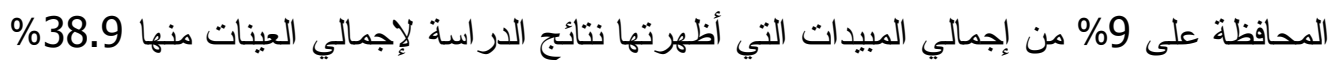
أعلى من الحد الأقصى المسموح به. جدول رقم (9) نسب التلوث بمحافظات عينة الار اسة

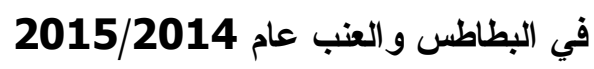

\begin{tabular}{|c|c|c|c|c|c|c|c|c|c|c|c|}
\hline \multicolumn{2}{|c|}{ المبيدات المتخطية } & \multicolumn{2}{|c|}{ إنمالي المبيات } & \multicolumn{2}{|c|}{ العينات المتفطية } & \multicolumn{2}{|c|}{ العينات الملوثة } & \multicolumn{2}{|c|}{ العينات الخالية } & \multirow{2}{*}{ 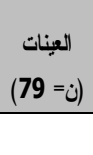 } & \multirow[t]{2}{*}{ المحافظة } \\
\hline$\%$ & العدد & $\%$ & العدد & $\%$ & العدد & $\%$ & العدد & $\%$ & العدد & & \\
\hline 10.5 & 6 & 28.4 & 57 & 30.8 & 4 & 92.9 & 13 & 7.1 & 1 & 14 & القاهرة \\
\hline 7.7 & 2 & 12.9 & 26 & 33.3 & 2 & 60.0 & 6 & 40.0 & 4 & 10 & المنوفية \\
\hline 17.1 & 6 & 17.4 & 35 & 40.0 & 4 & 58.8 & 10 & 41.2 & 7 & 17 & البحيرة \\
\hline 8.7 & 2 & 11.4 & 23 & 33.3 & 2 & 66.7 & 6 & 33.3 & 3 & 9 & الإسماعيلية \\
\hline 14.3 & 6 & 20.9 & 42 & 28.6 & 2 & 43.8 & 7 & 56.3 & 9 & 16 & المنيا \\
\hline 38.9 & 7 & 9.0 & 18 & 33.3 & 2 & 46.2 & 6 & 53.8 & 7 & 13 & أسيوط \\
\hline
\end{tabular}

المصدر: جمعت وحسبت من بيانات عينة الدراسة. 
ويتضح مما سبق أن محافظات وجه بحري كانت نسب التلوث بمنبقيات المبيدات بها أعلى

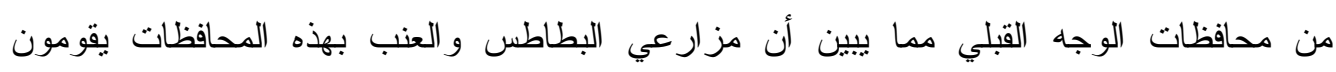
باستخدام المبيدات بإفر اط شديد وطرق لا نتسم بالكفاءة مما يتسبب في إهدار هذا المورد وارتفاع

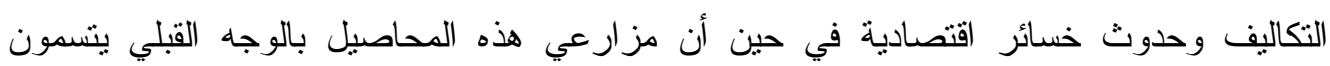
بالوعي و الكفاءة في استخدام المبيدات ويتضح ذلك من زيادة نسب العينات الملوثة وكذلك زيادة نسب العينات التي تخطت الحدود القصوى المسموح بها و أيضاً زيادة نسب المبيدات المستخدمة بهذه فئه

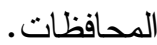

\section{4- قياس الأثز الإقتصادى لمتبقيات المبيدات في البطاطس والعنب:}

بناءً على نتائج العينة المعملية التى تم جمعها من بعض الأسوات الت المحلية بمحافظات دراسة العينة

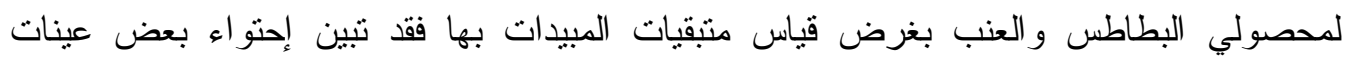
الدراسة على متبقيات مبيدات بنسب تتخطى الحد الأقصى المسموح به مما يجعلها غير صالحة

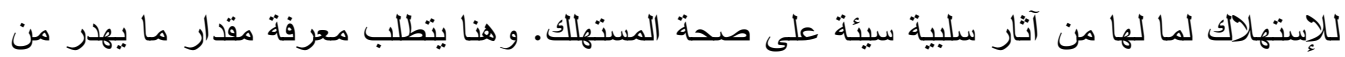

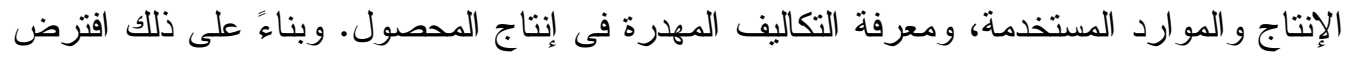
البحث أن نسبة العينات التى تخطت الحد المسموح به تمنل مقدار الفاقد من الإنتاج لمحصولي الدر اسة بناء على عدم صلاحينها للإستهلاك ويتضح ذلك كما يلي: أ- البطاطس: تبين من الجدول (10) أن عينات الدر اسة بمحافظتي المنوفية و البحيرة لم تحتوى على بلى منتقيات مبيدات تتخطى الحد المسموح به وبالتالى لا يوجد بها فاقد في الإنتاج نتيجة وجود متنقيات

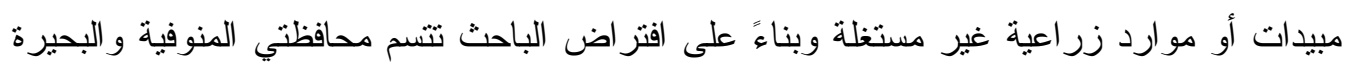
بالكفاءة الإقتصادية في استخدام المبيدات. أما محافظة الإسماعيلية فكان إجمالى العينات بهاء 5 عينات عينات و اتضح من نتائج تحليل العينة احتواء عينة على متنقيات مبيدات متخطية الحد المسموح به، تمثل نحو 20\% من إجمالى عينة المحافظة، وبناءً على افتر اض البحث فتعتبر هذه النسبة هي نسبة الفئه الفاقد

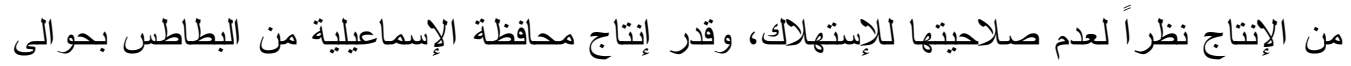
253.4 ألف طن بمساحة بلغت 18.4 ألف فدان، وقدر منوسط تكاليف المبيدات ومقاومة الآفات بحو الى 688.5 جنيه /فدان عام 2015، حيث يتضح أن فاقد الإنتاج قدر بحو الى 51 ألف طن من فن

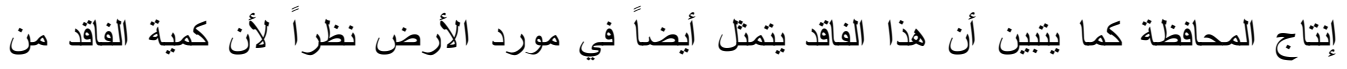
الإنتاج ينت إنتاجها من مساحة تقدر بحوالي 3.7 ألف فدان وبمتوسط نكلفة مبيدات ومقاومة فئنة آفات بلغت نحو 137.7 جنيه/فدان مما يوضح أن هذه المساحة لم يتم استغلالها بكفاءة وبالتالي هدر مورد

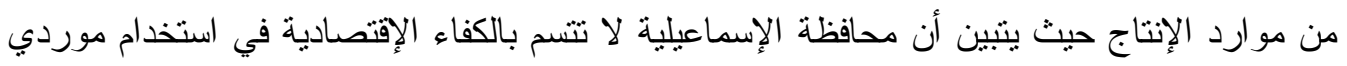
المبيدات و الأرض لإنتاج البطاطس.

أما محافظة المنيا فبلغ إجمالى العينات بها لهات 10 عينات وتبين إحتو اء عينة على متبقيات مبيدات متخطية الحد المسموح به، تمثل نحو 10\% من إجمالى عينة المحافظة، وبناءً على افتر اض البحث

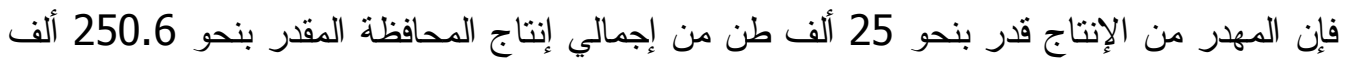

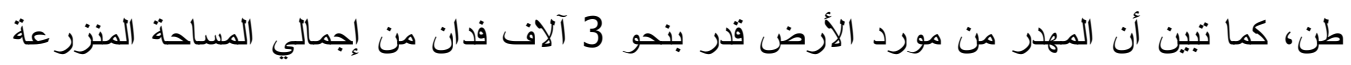


بالمحصول بالمحافظة والبالغة نحو 30.4 ألف فدان، بمتوسط نكلفة مبيدات ومقاومة آفات بلغت حو الي 68.9 جنيه/فدان من متوسط تكاليف المبيدات ومقاومة الآفات المقدرة بحو الى 688.5 جنية / فدان. فى حين أن محافظة أسبوط كان إجمالى العينات بها 7 عينات وتنين إحتواء عينة على متبقيات

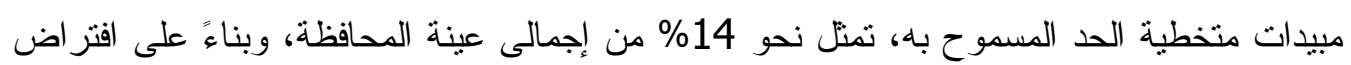
البحث فتعتبر هذه النسبة هي نسبة الفاقد من الإنتاج نظر اً لعدم صلاحيتها للإستهلاك، وقدر إنتاج محافظة أسيوط من البطاطس بحو الى 38.1 ألف طن بمساحة بلغت 2.8 ألف فدان، وقدر متوسط الإن الفي

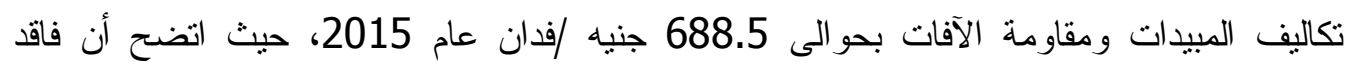

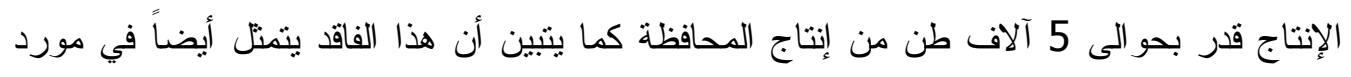

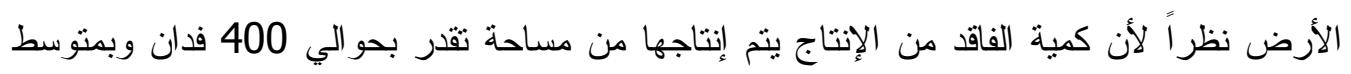
تكلفة مبيدات ومقاومة آفات بلغت نحو 98.5 جنيه/فدان مما يوضح أن هذه المساحة لم يتم استغلالها بكفاءة وبالتالي هدر مورد من موارد الإنتاج. وقد نبين أن كل من محافظات الإسماعيلية و المنيا

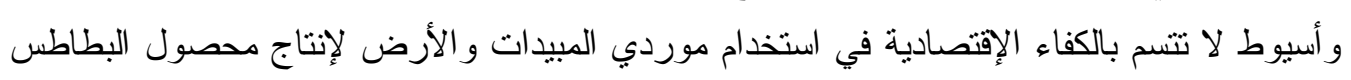

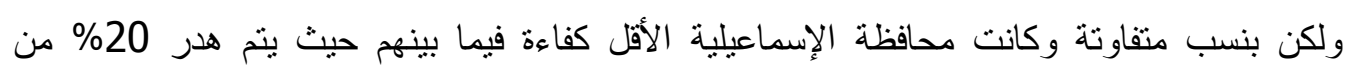
الإنتاج لتلوث المحصول بمنقيات المبيدات وعدم صلاحيته للإستهلالك نتيجة الإسر اف في إستخدام

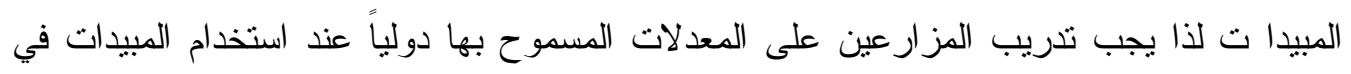

هذه المحافظات.

\section{جدول (10) مساحة وإنتاج ومتوسط تكلفة المبيدات والمهر منهما \\ لمحصول البطاطس عام 2015}

\begin{tabular}{|c|c|c|c|c|c|c|c|c|c|c|c|c|}
\hline \multicolumn{2}{|c|}{ 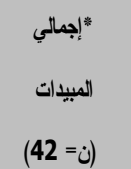 } & \multirow{2}{*}{ 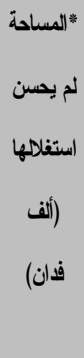 } & \multirow{2}{*}{ 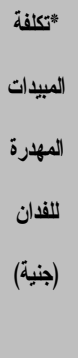 } & \multirow{2}{*}{ 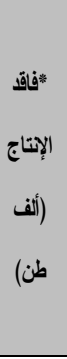 } & \multicolumn{2}{|c|}{ إلممالى العينات } & \multirow{2}{*}{ متك } & \multirow{2}{*}{$\begin{array}{l}\text { (الإتناج } \\
\text { (ألف) }\end{array}$} & \multirow{2}{*}{ (طن/فان) } & \multirow{2}{*}{ (ألف } & \multirow{2}{*}{$\begin{array}{l}\text { العينات } \\
= \\
\text { (44 }\end{array}$} & \multirow[t]{2}{*}{ المحافظة } \\
\hline$\%$ & العدد & & & & $\%$ & العدد & & & & & & \\
\hline 7.1 & 3 & 0.0 & 0.0 & 0 & 0.0 & 0.0 & 688.5 & 469.3 & 9.5 & 49.2 & 6 & المنوفية \\
\hline 16.7 & 7 & 0.0 & 0.0 & 0 & 0.0 & 0.0 & 688.5 & 958.6 & 11.8 & 81.5 & 9 & البحيرة \\
\hline 7.1 & 3 & 3.7 & 137.7 & 51 & 20 & 1.0 & 688.5 & 253.4 & 13.7 & 18.4 & 5 & الإسماعيلية \\
\hline 19.0 & 8 & 3.0 & 68.9 & 25 & 10 & 1.0 & 688.5 & 250.6 & 8.2 & 30.4 & 10 & المنيا \\
\hline 14.3 & 6 & 0.4 & 98.5 & 5 & 14.3 & 1.0 & 688.5 & 38.1 & 13.7 & 2.8 & 7 & أسيوط \\
\hline
\end{tabular}

المصدر: وزارة الزراعة واستصلاح الأراضي- قطاع الثئون الإقتصادية- الإدارة المركزية للإقتصاد الزراعي

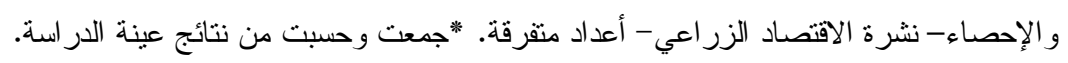




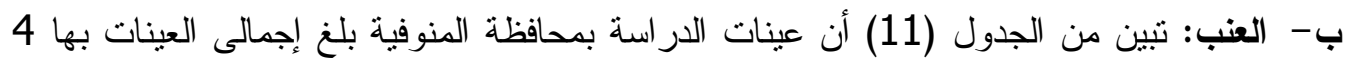

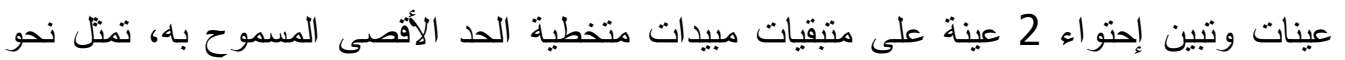
50\% من إجمالى عينات المحافظة، وبناءً على افتز اض البحث فتعتبر هذه النسبة هي نسبة الفاقد من

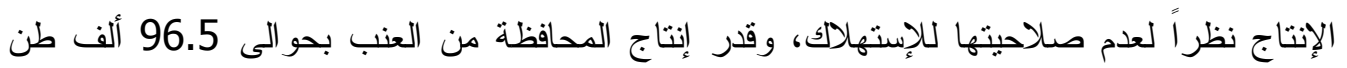
بمساحة بلغت 14.2 ألف فدان، وقدر منوسط نكاليف المبيدات ومقاومة الآفات بحو الى 2590 جنيه /فدان عام 2015، حيث اتضح أن فاقد الإنتاج قدر بنحو 48 ألف طن من إنتاج المحافظة وهدر في بـان المساحة يقدر بحوالي 7.1 ألف فدان وبمنوسط تكلفة مبيدات ومقاومة آفات بلغت نحو 1295 جنيه/فدان مما يوضح أن هذه المساحة لم يتم استغلالها بكفاءة وبالتالي هدر مورد من موارد الإنتاج.

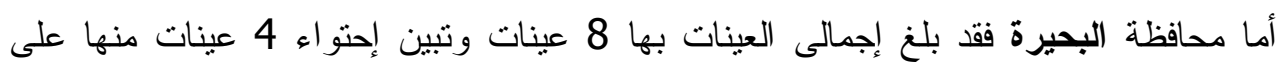
متبقيات مبيدات متخطية الحد الأقصى المسموح به، تمنل نحو 50\% من إجمالى عينات المحافظة، وبناءً على افتراض البحث فتعتبر هذه النسبة هي نسبة الفاقد من الإنتاج نظراً لعدم صلاحيتها

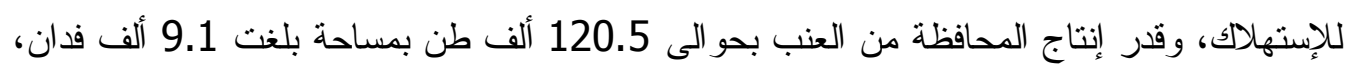
وقدر متوسط تكاليف المبيدات ومقاومة الآفات بحو الى 2590 جنيه /فدان عام 2015، حيث التي الضح أن فاقد الإنتاج قدر بحو الى 60 ألف طن من إنتاج المحافظة وهدر في المساحة يقدر بحو الي 4.5

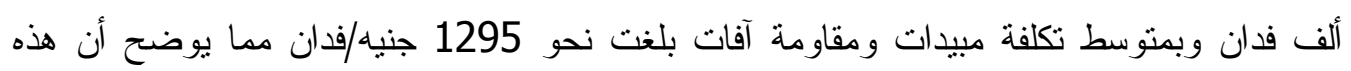
المساحة لم يتم استغلالها بكفاءة وبالتالي هدر مورد من موارد الإنتاج.

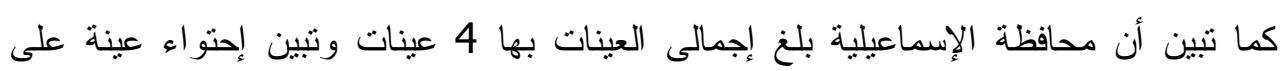

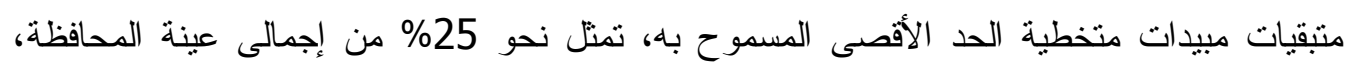
وبناءً على افتراض البحث فتعتبر هذه النسبة هي نسبة الفاقد من الإنتاج نظراً لعدم صلاحيتها للإستهلاك، وقدر إنتاج المحافظة من العنب بحو الى 11.4 ألف طن بمساحة بلغت 1.6 ألف فدان، إنه

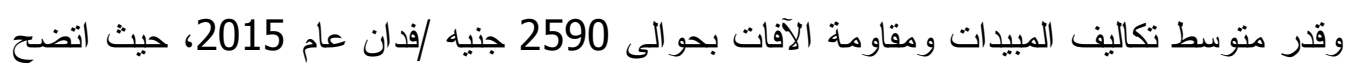
أن فاقد الإنتاج قدر بنحو 3 آلاف طن من إنتاج المحافظة وهدر في المساحة يقدر بحو الي 400 فدان

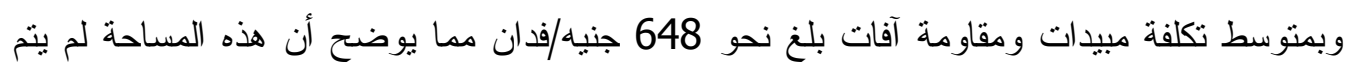
استغلالها بكفاءة وبالتالي هدر مورد من موارد الإنتاج.

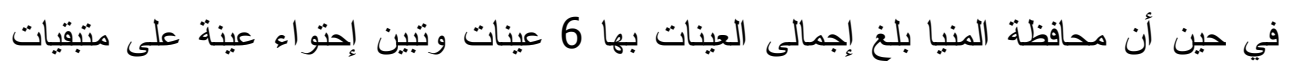

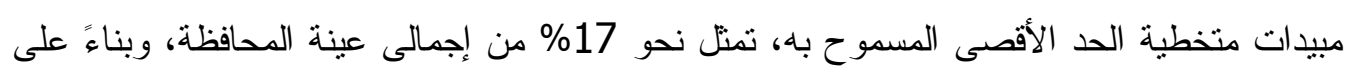

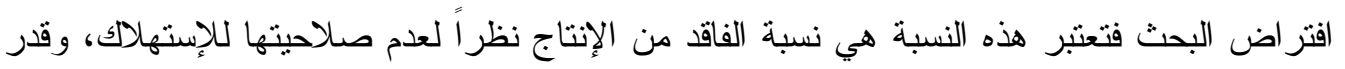

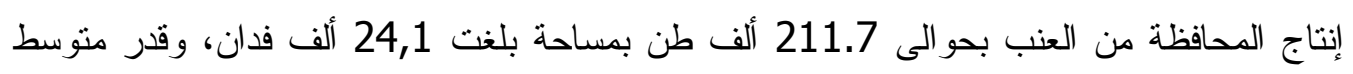
تكاليف المبيدات ومقاومة الآفات بحو الى 2590 جنيه /فدان عام 2015، حيث التصح أن فئه فاقد الإنتاج قدر بنحو 35 ألف طن من إنتاج المحافظة وهدر في المساحة يقدر بحو الي 4 آلاف فدان وبمتوسط تكلفة مبيدات ومقاومة آفات بلغت نحو 433 جنيد/فدان مما يوضح أن هذه المساحة لم يتم استغلالها بكفاءة وبالتالي هدر مورد من موارد الإنتاج. 
و أخيراً محافظة أسيوط فكان إجمالى العينات بها 6 عينات ومن نتائج تحليل العينات تبين احتو اء عينة على منتقيات مبيدات متخطية الحد المسموح به، تمثل نحو 17\% من إجمالى عينات المبات المحافظة، وبناءً على افتراض البحث فتعتبر هذه النسبة هي نسبة الفاقد من الإنتاج نظراً لعدم صلاحيتها للإستهلاك، وقدر إنتاج المحافظة من العنب بحو الى 28.6 ألف طن بمساحة بلغت 2.4 ألف فدان، وقدر متوسط تكاليف المبيدات ومقاومة الآفات بحو الى 2590 جنيه /فدان عام 2015، حيث التين التصح أن فاقد الإنتاج قدر بنحو 5 آلاف طن من إنتاج المحافظة و هدر في المساحة قدر بحو الي 400 فدان

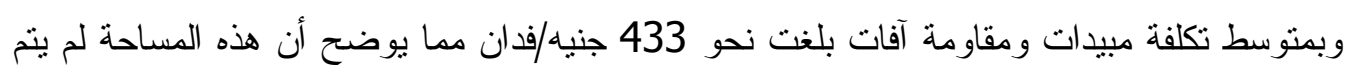

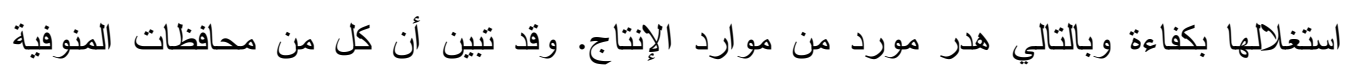

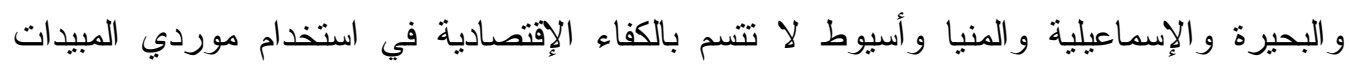
و الأرض لإنتاج محصول العنب ولكن بنسب متفاوتة وكانت محافظتي المنوفية والبحيرة الأقل كفاءة فيما بينهم حيث يتم هدر 50\% لكل منهما من إنتاج العنب لتلوثه بمنتقيات المبيدات المتخطية للحد الأقصى المسموح به و عدم صلاحيته للإستهلاك نتيجة الإسر اف في إستخدام المبيدات و الذي يؤثر لئز على صحة المستهلكين.

جدول (11) مساحة وإنتاج ومتوسط تكلفة المبيدات والمهذر منهما لمحصول العنب عام 2015

\begin{tabular}{|c|c|c|c|c|c|c|c|c|c|c|c|c|}
\hline \multicolumn{2}{|c|}{ 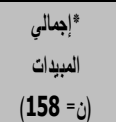 } & \multirow{2}{*}{ 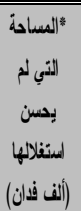 } & \multirow{2}{*}{ 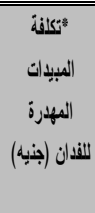 } & \multirow{2}{*}{ (أفن طناة) } & \multicolumn{2}{|c|}{ هن إجمالى العبنات } & \multirow{2}{*}{ 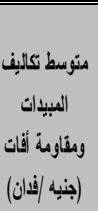 } & \multirow{2}{*}{ (النف طن) } & \multirow{2}{*}{ الإنادية } & \multirow{2}{*}{ الفادانة (ألف } & \multirow{2}{*}{ 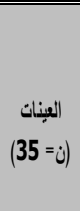 } & \multirow[t]{2}{*}{ المدافظة } \\
\hline$\%$ & العدد & & & & $\%$ & العلد & & & & & & \\
\hline 13.9 & 22 & 7.1 & 1295 & 48 & 50 & 2.0 & 2590 & 96.5 & 6.8 & 14.2 & 4 & المنوفية \\
\hline 17.7 & 28 & 4.5 & 1295 & 60 & 50 & 4.0 & 2590 & 120.5 & 13.3 & $\begin{array}{c}9.1 \\
\end{array}$ & 8 & البديرة \\
\hline 12.7 & 20 & 0.4 & 648 & 3 & 25 & 1.0 & 2590 & 11.4 & 7.3 & 1.6 & 4 & الإسماعلية \\
\hline 21.5 & 34 & 4.0 & 433 & 35 & 16.7 & 1.0 & 2590 & 211.7 & 8.8 & 24.1 & 6 & المنيا \\
\hline 7.6 & 12 & 0.4 & 433 & 5 & 16.7 & 1.0 & 2590 & 28.6 & 12.0 & 2.4 & 6 & أسيوط \\
\hline
\end{tabular}

المصدر: وزارة الزراعة واستصلاح الأراضي- قطاع الثئون الإقتصادية- الإدارة المركزية للإقتصاد الزراعي

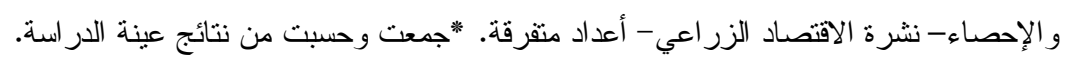

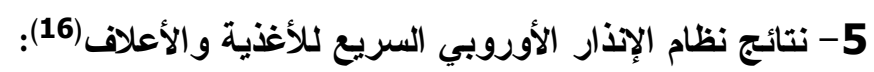

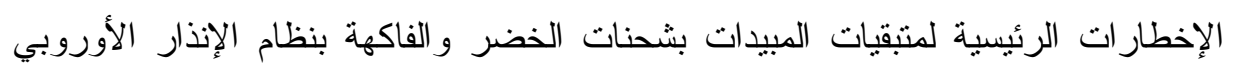
السريع للأغذية والأعلاف (RASFF) خلا الفترة من (2013-2015) كانت 108 إخطار خلاد

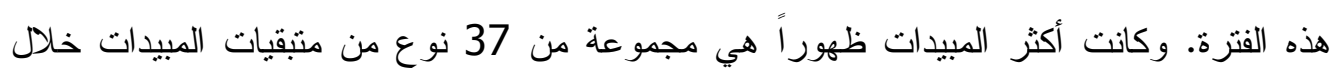

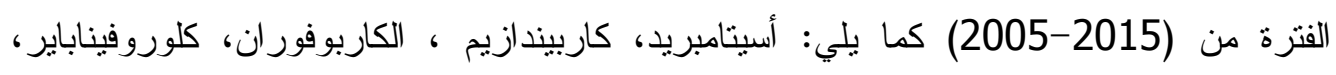

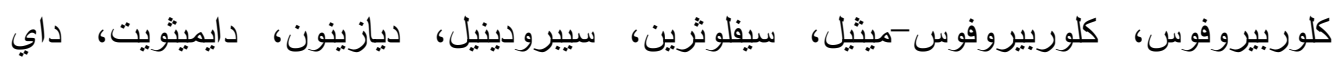

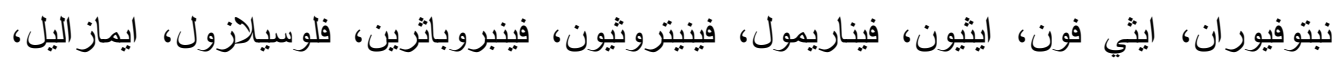

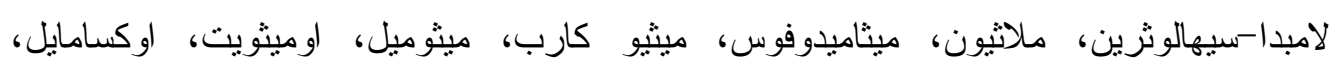


فينتويت، بروسايميدون، بروبارجايت، بروفينوفوس، بروبي كونازول، بايريدلايل، ثيابندازول،

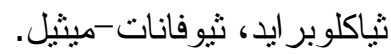

وكانت أكثر هذه المركبات متطابقة مع نتائج عينات الدر اسة مما يسبب حدوث خسائر كبيرة

في الصادرات المصرية نظر اً لرفض الثحنات التي تتخطى الحدود المسموح بها و أيضاً لقيام الإتحاد الأوربي بحظر تصدير المحاصيل التي يتكرر وجود منتقيات بها لفترات قد نصل إلى أكثر من سنتين، كما أن دول الخليج أيضاً قد اتجهت إلى الإهتمام بسلامة الأغذية وتطبيق نظام حظر تصدير المحاصيل التي يوجد بها منتقيات مبيدات وقد أدى ذلك إلى قيام كل من السعودية و الإمارات و الكويت بالإضافة إلى لبنان بحظر بعض صادرات المحاصيل المصرية ومنها الطماطم والفراولة و الفلفل و الجو افة و البرتقال نظراً لتكر ار تصدير شحنات تحتوي على متبقيات المبيدات مما أدى ذلك ولك إلى حدوث خسائر اقتصادية كبيرة.

وقد اتضح الدور الهام لوجود المعامل الحكومية المعتمدة في مجال متبقيات المبيدات من حيث المساهمة في رفع كفاءة الصادرات المصرية بخلوها من منتقيات المبيدات وتحليل عينات

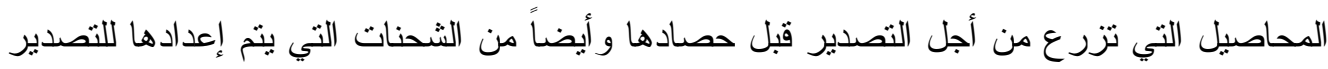
ويتم سحبها بو اسطة الحجر الزر اعي المصري مما يكون مؤشر قوي بساعد المُصدر في اتخاذ قرار

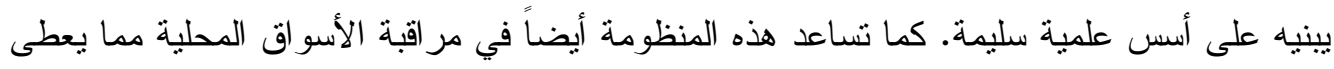
مؤشرات لمتخذي القرار و الجهات الرقابية على الأسواق مما يؤدي إلى خفض استخدام منتقيات المبيدات و الحفاظ على صحة المستهلك.

\section{الملثنـــإس}

نظراً لتعرض المحاصيل الزراعية لكثير من الآفات والأمر اض بسبب التغيرات المُنَاخية مما لها

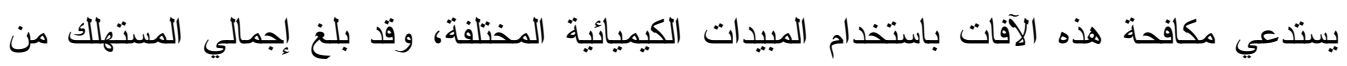
المبيدات الزراعية في مصر حوالي 8.5 ألف طن مادة فعالة وقد أدى تعدد أنواع المبيدات

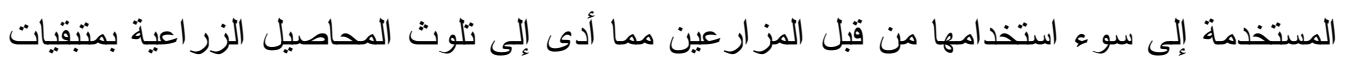

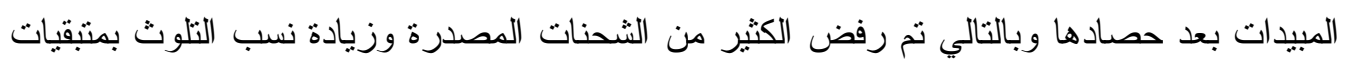
المبيدات بالمنتجات الزر اعية بالأسو اق المحلية.

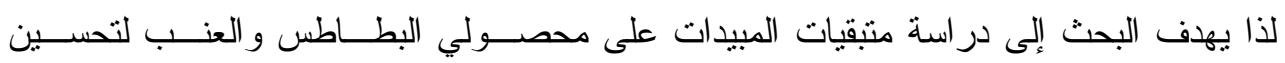

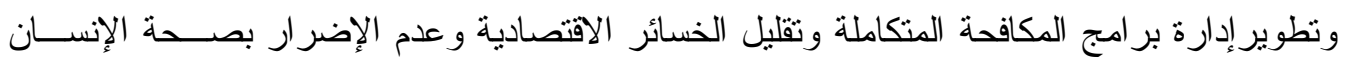

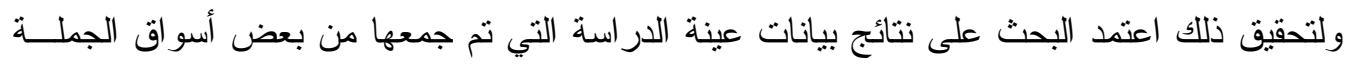

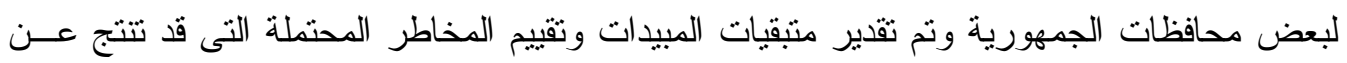

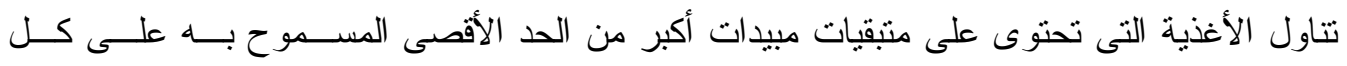
محصول. كما استتد البحث إلى أساليب التحليل الإحصائي من الناحيتين الوصفية و الكمية، كاســتخدام الأساليب الإحصائية البسيطة منل النسب المئوية و المتوسطات الحسابية، إلى جانب استخدام نموذج الإنحدار

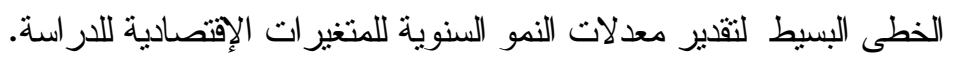




\section{وقد توصل البحث إلى النتائج التالية:}

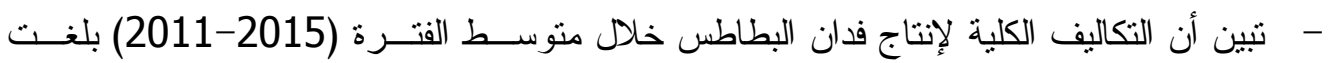

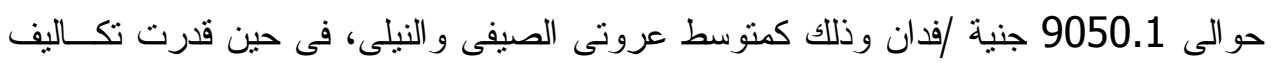

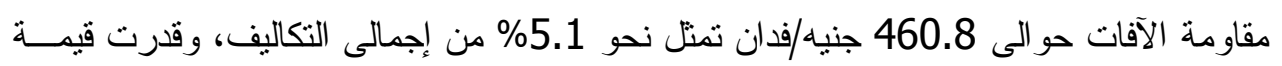

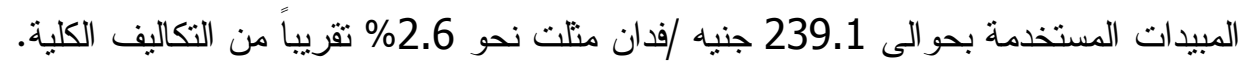
- تبين أن التكاليف الكلية لإنتاج فدان من العنب خلال منوسط نفس الفترة بلغ حو الى 17566.2

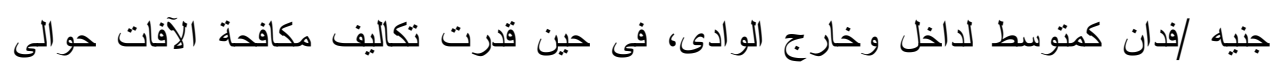

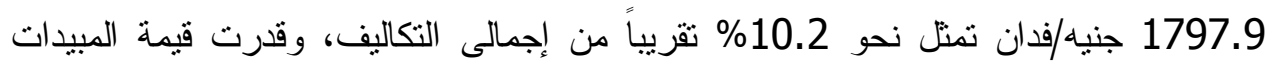

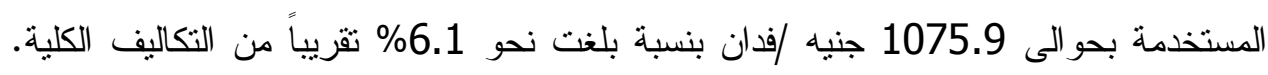

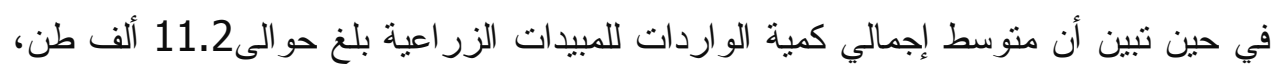

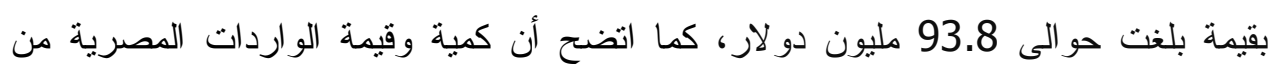
إجمالى المبيدات أخذ اتجاهاً نحو التزايد بمعدلات نمو مختلفة لكل من الأنواع الثلاثة (حشرية، لونة

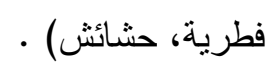
- أظهرت نتائج تحليل عينات الدراسة و التي اشتنلت على 79 عينة منها 35 عينة لمحصول العنب، 44 عينة لمحصول البطاطس. أن عدد العينات الخالية من متبقيات المبيدات 31 عينة

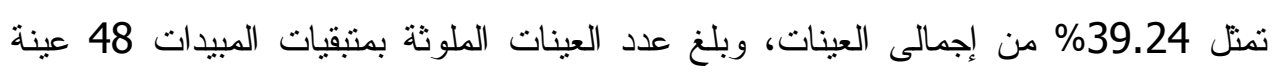
تمنل 60.76\% من إجمالى العينات، وكان عدد العينات التى تخطت الحد الأقصى المسموح به عند من متبقيات المبيدات قدرت بنحو 16 عينة بنسبة 33.3\% من عن إجمالى العينات الملوثة بمنتقيات المبيدات تقريباً. - أظهرت نتائج تقصي منبقيات المبيدات في محصول البطاطس أن حوالي 38.6\% من إجمالى العينات كانت ملوثة بمتبقيات المبيدات، وأن 23.5\% من إجمالي العينات الملوثة قد الحتوت

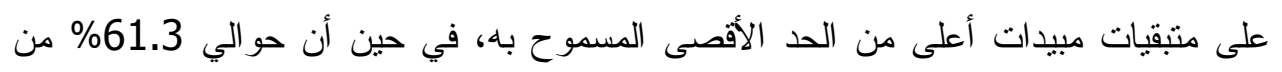

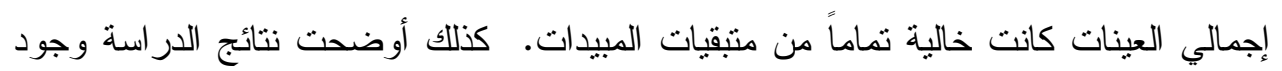
24 متبقي مبيد مختلف في عينات البطاطس وجد بعضها أكثر من مرة بإجمالي 42 مبيد منهم 16 متبقي مبيد أعلى من الحد الأفصى المسموح به.

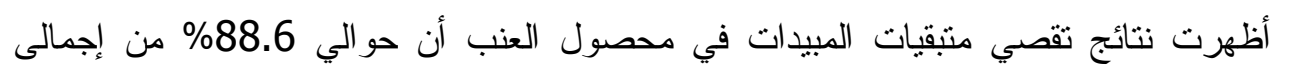
العينات كانت ملوثة بمنقبات المبيدات، وأن حوالي 38.7\% من فئن إجمالي العينات الملوثة قد

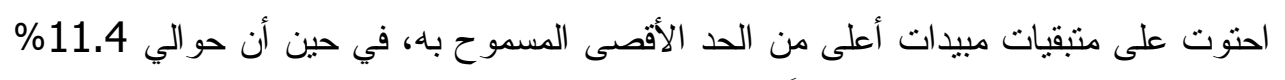

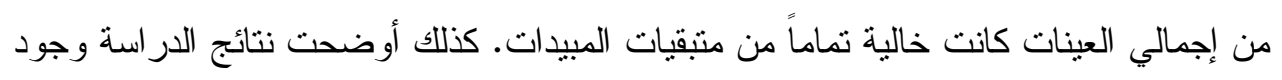
36 متبقي مبيد مختلف في عينات العنب وجد بعضها أكثر من مرة بإجمالي 159 مبيد منهم

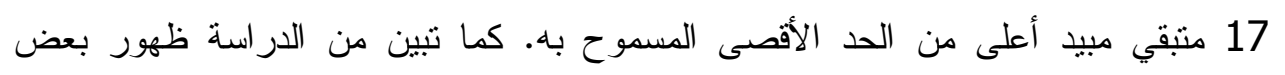


المبيدات الكلورونية العضوية الممنوعة منذ عام 1972م تقريباً في بعض عينات محصول البطاطس بمحافظة أسيوط.

- توضح نتائج الدراسة وجود بعض المبيدات التي تخطت الحد المسموح نتاوله يومياً وفقاً لما حددته منظمة الأغذية والزر اعة ومنظمة الصحة العالمية وهي: الكاربوفيوران بمؤشر خطورة قدر بنحو 1128\% أي بنسبة تزيد عن المسموح نتاوله يومياً بنحو 1028\%، يليه مبيد الدايزينون بمؤشر خطورة بنسبة بلغت نحو 168\% أبي بنسبة نزيد عن بن المسموح نتاوله يومياً بنحو 68\%

تبين من حساب تحليل المخاطر الصحية المرتبطة بالتعرض لمتبقيات المبيدات التي تخطت الحد

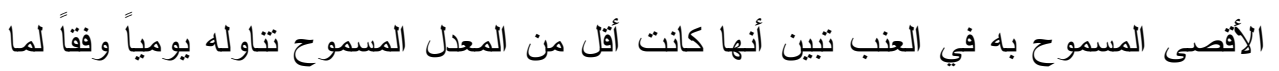

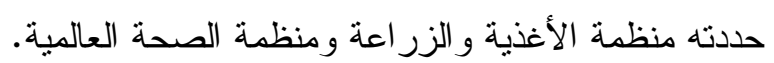

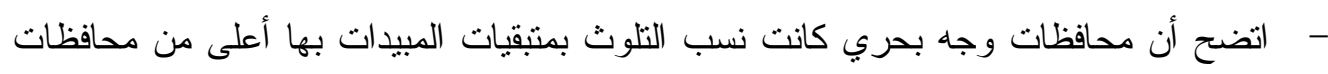
الوجه القبلي مما يبين أن مزارعي البطاطس والعنب بدحافظات الوجه البحري يقومون

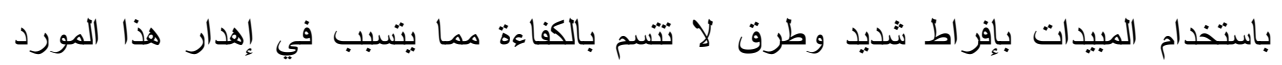

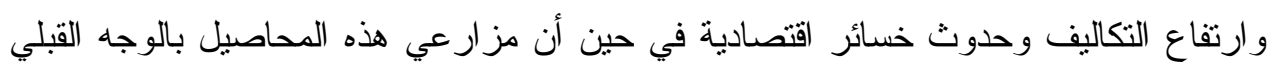
يتسمون بالوعي و الكفاءة في استخدام المبيدات ويتضح ذللك من زيادة نسب العينات الملوثة

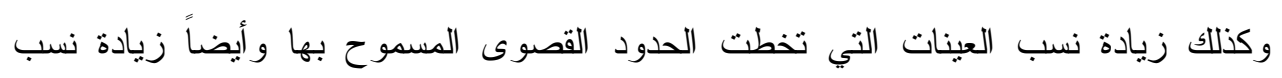
المبيدات المستخدمة بهذه المحافظات. تنين من دراسة الأثز الإقتصادي لمتبقيات المبيدات على محصولي البطاطس و العنب أن

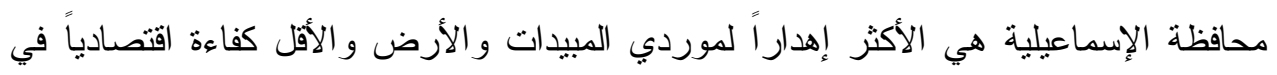
زر اعة البطاطس بنحو 20\% ، في حين أن محافظتي الهنوفية و البحيرة هما الأكثر إهداراً

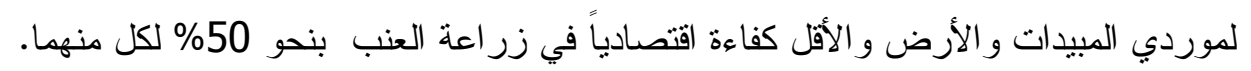
التوصيات

أولاً: المؤسسات الحكومية:

1- تشديد الرقابة على المبيدات الممنوع استخدامها وتتبع المبيدات المهربة لمنع تداولها بالأسواق.

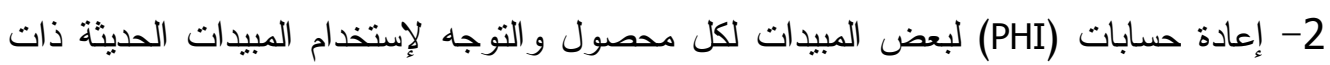
- القصير (PHI) 3- زيادة التوعية و التدريب للمز ارعين بمحافظات الوجه البحري لترشيد استخدام المبيدات وطرق

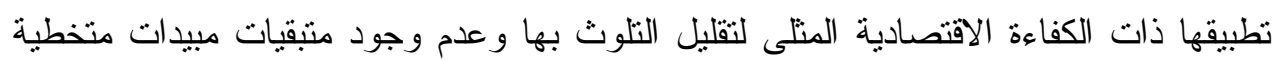
للحدود المسموح بها. 4- قيام جهاز سلامة الغذاء بالتعاون مع الأجهزة الحكومية المنوطة بوضع نظام رقابي للأسو اق

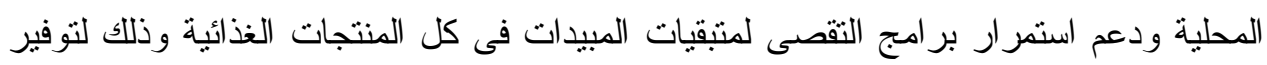
وتحديث قاعدة بيانات يمكن عن طريقها تتفيذ الاستر اتيجيات المستقلية لمكافحة الآفات وحماية 
المستهلك من التعرض العشوائى للمبيدات، وزيادة الوعى لاى المستهلكين بعطيات الطهى و التحضير المناسبة والتى تعمل على التخلص من منتقيات المبيدات فى الخضر و الفاكهة.

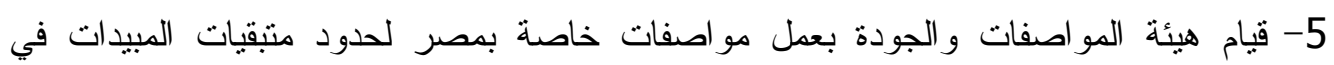
المنتجات الزراعية المتداولة بالأسواق المحلية تكون منطلباتها اعلى من منطلبات الكودكس

$$
\text { للحفاظ على المستهلك المصري. }
$$

6- تثديد العقوبات على الثركات المصدرة التي يتم رفض شحناتها لوجود متنقيات مبيدات بها و إعلان إسم هذه الشركات في الإعلان وعدم السماح بتداول منتجاتها بالأسو اق المحلية. ثانياً: القطاع الخاص: 1- توجيه منتجي محصول العنب بترشيد استخدام المبيدات نظراً لقيامهم باستخدام كميات كبيرة

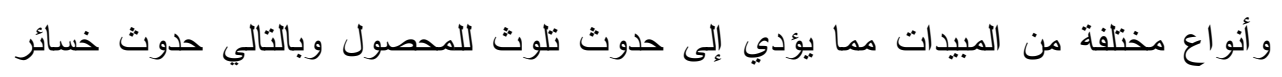
اقتصادية كبيرة.

2- قيام شركات إنتاج المبيدات بدورها في الإرشاد الزر اعي و التوعية و التوجيه لكنتجي المحاصيل الزراعية ومطبقي المبيدات من خلال عقد الندوات وورش العمل لتوضيح طرق الإديد الإنتخدام الأمثل للمبيدات و أفضل طرق تطبيقها على المحاصيل للوصول إلى النتائج المأمولة.

ثالثاً: الجامعات والمعاهد البحثية: 1- قيام المعاهد و المعامل البحثية بإجر اء التحليلات اللازمة لعمل خريطة جغر افية بمناطق التلوث

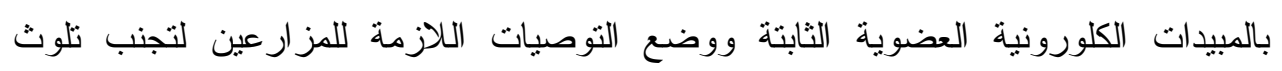
المحاصيل بها.

2- العمل على وصول نتائج البحوث في هذا المجال ونتائج دراسات تقصي الملوثات في الأغذية

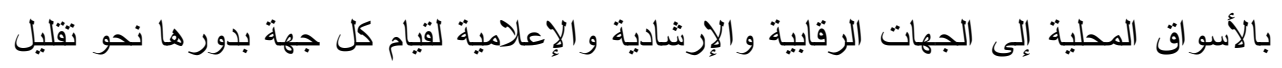

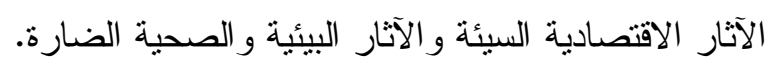

$$
\text { المر اجع }
$$

أولاً: مراجع باللغة العربية:

1- الجهاز المركزي للتعبئة العامة والإحصاء، شبكة مركز المعلومات (www.capmas.gov.eg).

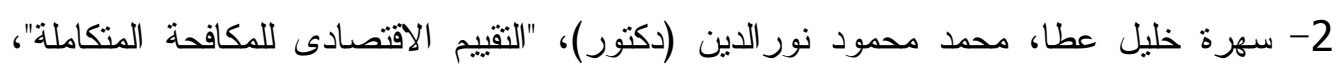

المجلة المصرية للإهتصاد الزر اعى، المجلد السادس و العشرون، العدد الثانى، يونيو 2016.

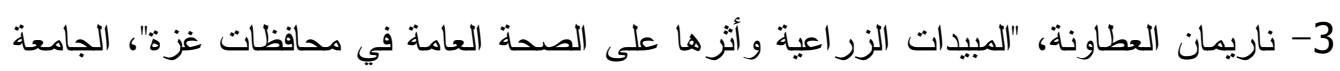
الإسلامية، غزة، فسلطين، 2016.

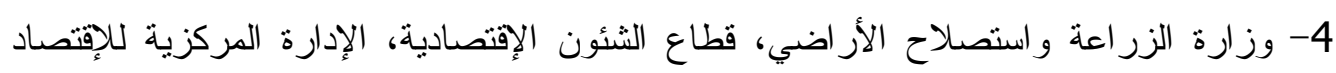
الزر اعي و الإحصاء، لجنة مبيدات الآفات الزر اعية، أعداد متفرقة.

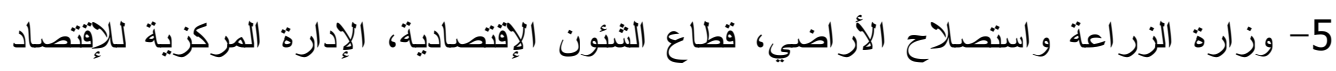

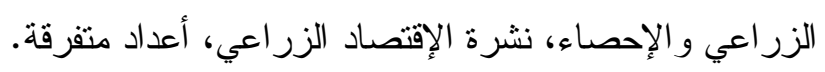




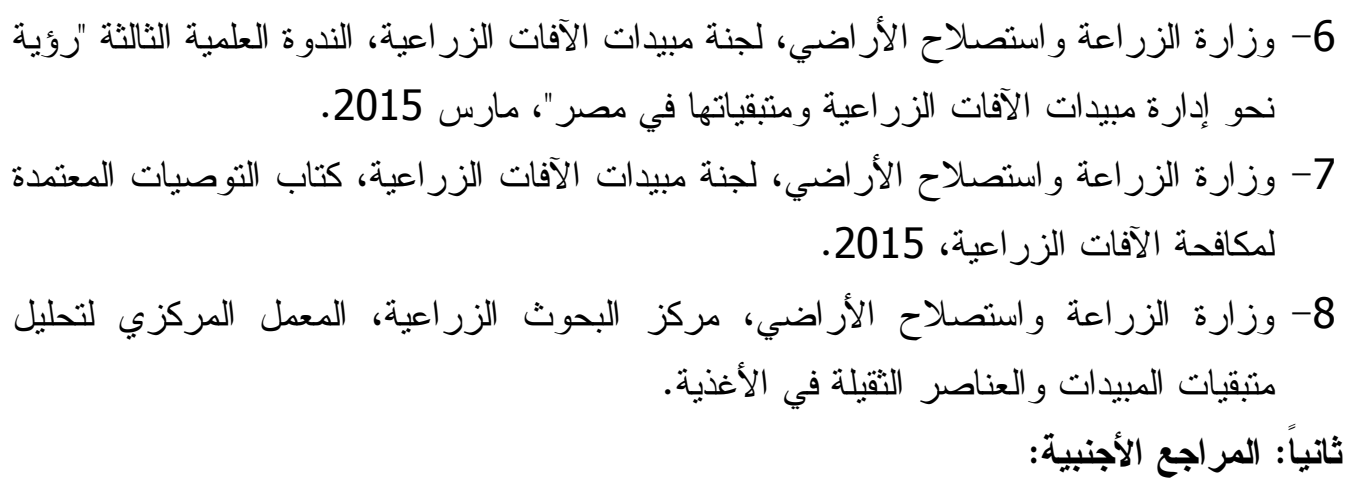

9- Anastassiades, M., Lehotay, S.J., Štajnbaher, D, Schenck, F.J., (2003). "Fast and easy multiresidue method employing acetonitrile extraction/partitioning and dispersive solidphase extraction for the determination of pesticide residues in produce". J. AOAC Int., 86: 412-431.

10- Banerjee, K., Mujawar, S., Utture, S.C., Dasgupta, S., Adsule, P.G., (2013). "Optimization of gas chromatography-single quadrupole mass spectrometry conditions for multiresidue analysis of pesticides in grapes in compliance to EUMRLs". Food Chemistry, 138: 600-607.

11- Chen, C., Qian, Y., Chen, Q., Tao, C., Li, C., Li, Y., (2011). "Evaluation of pesticide residues in fruits and vegetables from Xiamen", China. Food Control, 22:1114-1120.

12- European Commission, (2010). EU Pesticides database. Available from: <http://ec.europa.eu/sanco_pesticides/public/index.cfm.<

13- FAO/WHO (Food and Agriculture Organization/World Health Organization), (2004). Food standards programme, Codex Alimentarius Commission, Twentyseventh Session, Geneva, Switzerland, 28 June - 03 July 2004.

14- FAO/WHO, (2008). Dietary exposure assessment of chemicals in food. Report of a joint FAO/WHO consultation, Annapolis, Maryland, USA, 2-6 May 2005.

15- F.I. Eissa1, A.A. Helalia, M.A. Khorshid, M.A. El-Sisi, "Monitoring of multi-class pesticide residues in green grape and their potential risk for Egyptian consumers", Nature and Science 2013;11(11), www.sciencepub.net/nature/ns.

16- Food and Feed Safety Alerts, http://ec.europa.eu/food/safety/rasff/portal en.

17- Mahmoud El-sisi, "Studies on risk analysis of some organ phosphorus pesticides in food", M.Sc Dissertation, Department of Environment and Bio-Agriculture, Faculty of Agriculture, Al-Azhar University, 2014.

18- WHO, (1997). Guidelines for predicting dietary intake of pesticide residues (revised) global environment monitoring system - food contamination monitoring and assessment programme (GEMS/Food) in collaboration with Codex Committee on pesticide residues. Programme of Food Safety and Food Aid, pp. 1-44.

19- WHO/GEMS/FOODS (2006). WHO/Global Environment Monitoring System-Food Contamination Monitoring and Assessment Program. Consumption cluster diets. <http://www.who.int/foodsafety/chem/gems/en/>. 